\begin{tabular}{|c|c|c|}
\hline Beitr. Ent. & Keltern & ISSN 0005-805X \\
\hline $51(2001) 1$ & S. $161-213$ & 14.09 .2001 \\
\hline
\end{tabular}

\title{
Contribution to the Lepidoptera fauna of the Madeira Islands Part 2. Tineidae, Acrolepiidae, Epermeniidae
}

\author{
With 127 figures
}

\section{REINHARD GAEDIKE and OLE KARSHOLT}

\section{Summary}

A review of three families Tineidae, Epermeniidae and Acrolepiidae in the Madeira Islands is given. Three new species: Monopis benderickexi sp. n. (Tineidae), Acrolepiopsis mauli sp. $\mathbf{n}$. and A. infundibulosa sp. $\mathbf{n}$. (Acrolepiidae) are described, and two new combinations in the Tineidae: Ceratobia oxymora (MEYRICK) comb. n. and Monopis barbarasi (KOCAK) comb. n. are listed. Trichophaga robinsoni nom. $\mathrm{n}$. is proposed as a replacement name for the preoccupied T. abriptella (WOLLASTON, 1858). The first tecord from Madeira of the family Actolepiidae (with Acrolepiopsis vesperella (ZELLER) and the two above mentioned new species) is presented, and three species of Tineidae: Stenoptinea cyaneimarmorella (MILLIÈRE), Ceratobia oxymora (MEYRICK) and Trichopbaga tapetzella (IINNAEUS) are reported as new to the fauna of Madeira. The Madeiran records given for Psychoides filicivora (MEYRICK) are the first records of this species outside the British Isles. Tinea pellionella LINNAEUS, Monopis laevigella (DENIS \& SCHIFFERMÜLLER) and M. imella (HUBBNER) are deleted from the list of Lepidoptera found in Madeira. All species and their genitalia are figured, and information on bionomy is presented.

\section{Zusammenfassung}

Es wird eine Übersicht über die drei Familien Tineidae, Epermeniidae und Acrolepiidae auf den Madeira Inseln gegeben. Die drei neuen Arten Monopis benderickxi sp. $\mathbf{n}$. (Tineidae), Acrolepiopsis mauli sp. n. und $A$. infundibulosa sp. n. (Acrolepiudae) werden beschrieben, zwei neue Kombinationen bei den Tineidae: Ceratobia oxymora (MEYRICK) comb. n. und Monopis barbarosi (KOC,AK) comb. n. werden aufgeführt. Trichophaga robinsoni nom. n. wird als Ersatzname für den präokkupierten Namen T. abruptella (WOLLASTON, 1858) eingesetzt. Die Familie Acrolepiidae (mit A. vesperella (ZELIER) und den zwei unten neu beschriebenen Arten) wird erstmals auf Madeira nachgewiesen, wie auch die drei Tineidenarten Stenoptinea cyaneimarmorella (MILliÈRE), Ceratobia oxymora (MEYRICK) und Trichophaga tapetzella (LINNAEus). Die Funde von Psycboides filicivora (MEYRICK) auf Madeira sind die ersten Nachweise außerhalb der Btitischen Inseln. Tinea pellionella LINNAEUS, Monopis laevigella (DENIS \& SCHIFFERMÜLLER) und $M$. imella (HÜBNER) werden aus der Liste der Madeira-Lepidopteren gestrichen. Alle Arten und deren Genitalien werden abgebildet, es werden Informationen zur Bionomie gegeben.

\section{Keywords}

Madeira; Microlepidoptera; Tineidae; Epermeniidae; Acrolepiidae; Laurisilva 
The present paper deals with 21 species of Tineidae, 3 species of Acrolepiidae and one species of Epermeniidae. These 25 species constitute about $8 \%$ of the about 300 species of Lepidoptera found in Madeira. However, these three families are among the least known and collected Lepidoptera in Madeira. Out of these 25 species three are described as new in the present paper, and four others are recorded from Madeira for the first time.

The first species of Tineidae were collected by T. V. WOLLASTON around 1850 and two of them were described by WOLLASTON himself (1858). He also collected the first specimens of the only Madeiran representative of the Epermeniidae, but this find was published by WALSINGHAM (1894a). Contrary to this the family Acrolepiidae remained undetected until 1993, and the first records (including the description of two new species) is presented below. For a general account of Madeita from a lepidopterological point of view see KARSHOLT (2000).

\author{
Abbreviations \\ AMFA: $\quad$ coll. ANTONIO M. F. AgUIAR, Camacha, Madeira \\ AREN: coll. E. ARENBERGER, Vienna, Austria \\ BMNH: The Natural History Museum, London, U.K. \\ DEI: Deutsches Entomologisches Institut im ZALF e. V., Eberswalde, Germany \\ HEN: $\quad$ coll. H. HENDERICKX, Mol, Belgium \\ JPC: $\quad$ coll. J. PASSOS DE CARVALHO, Oeiras, Portugal \\ MEY: $\quad$ coll. M. MEYER, Perl-Kesselingen, Germany \\ MMF: $\quad$ Museu Municipal do Funchal, Madeira \\ NMNH: National Museum of Natural History, Washington, D.C., U.S.A. \\ RMNH: National Museum of Natural History, Leiden, The Nederlands \\ ZMUC: $\quad$ Zoological Museum, University of Copenhagen, Denmark \\ ZMUH: $\quad$ Zoological Museum, University of Helsinki, Finland
}

\title{
Tineidae
}

Members of this family can, among other things, normally be recognized by having lateral bristles on the labial palpi. Because of the small number of species of this family occuring in Madeira, most of them can be recognized without examining their genitalia. However, one should keep in mind that additional species, resembling those already found in the islands, may well turn up. We have verified 21 species of Tineidae from the Madeira Islands, but only about one third of them are likely to belong to the original fauna of these islands, whereas the occurence of the other two-thirds seems to be a result of human activity.

Tenaga nigripunctella (HAWORTH, 1828)

[ $=$ pomiliella CLEMENS, 1862 ; = moeniella ROSSLER, 1877; = linobola MEYRICK, 1893; = sesquitertia MEYRICK, 1909]

Literature records from Madeira:

Tinea nigripunctella HAWORTH; WALSINGHAM, 1894a: 537, 541; WALSINGHAM, 1894b: 50; REBEL, 1901: 238; REBEL, 1917: 13; REBEL, 1940b: 8; REBEL, 1940c: 10, 46.

Tenaga nigripunctella (HAWORTH); PASSOS DE CARVALHO, 1995: 560, 575; VIEIRA, 1997: 7;

VIEIRA, 1998: 102. 
General distribution:

Palearctic region: in Europe sporadically known from the Iberian Peninsula, Great Britain, The Netherlands, Switzerland, Italy, Croatia, Greece, Russia. Additionally there are records from the Canary Islands, Morocco and southern Africa. ROBINSON \& NIELSEN (1989: 77) regarded records form Nearctic and Australian regions as results of accidential introduction.

Adult (fig: 1). T. nigripunctella can be recognized by its relatively small size (wingspan: 7-10 mm), and by having the forewings yellowish, marmorated with blackish brown.

$\sigma^{*}$-genitalia (figs. 33-35).

o genitalia (fig. 36).

Bionomy: Larvae in cases on lichens, found on old fences.

In Madeira found singly from July to October, mostly near the sea.

Material examined:

1 \&, Madeira, leg. T. V. WOLLASTON (BMNH);

19, Lombo Bon Vista, Funchal, 8.VIII.1980 (AMFA);

10 , Funchal, 16.IX.1994, leg. M. \& E. ARENBERGER; (AREN);

$10^{7}$, Porto Moniz, sea lev., 12.X.1994, leg. O. Karsholt (ZMUC);

$10^{*}$, Ponta do Sol, 16.X.1994, sea lev., leg. O. KARSHOLT (ZMUC);

$10^{*}$, Porto Santo, 23.X.1994, leg. O. Karsholt (ZMUC);

1 ơ, Amparo, São Martinho, 22.VII.1998, leg. J. JESus (AMFA).

Stenoptinea cyaneimarmorella (MILLIĖRE, 1854)

[ = angustipennis HERRICH-SCHÄFFER, 1854]

General distribution:

All of Europe (from France to Poland and Scandinavia, Northern Italy, Sardinia, Balkan Peninsula, hitherto unknown only in Albania and Bulgaria); Lebanon; Algeria; Far East (Russia: Primorje).

Adult (fig. 2-3). Differs from other Tineidae found in Madeira (apart from Oinophila $\nu$ flava-compare that species) by its slender wings, and by having the forewings blackish, motteled with whitish, yellowish, brownish and orange scales. It resembles somewhat Neomariania rebeli (WALSINGHAM, 1894) (Oecophoridae, Stathmopodinae), but the latter has longer, upcurved labial palps without lateral bristles.

0 -genitalia (fig. 40-42).

o-genitalia (fig. 37-39).

Bionomy: Larvae on lichens on old Plum trees and into the wood of these trees.

Two of the Madeiran specimens were beaten from foliage of Castanea sativa (A. AGUIAR, in litt.).

Material examined:

$10^{*}$, nördlich Ponta do Pargo, 9. IX. 1994, leg. M. \& E. ARENBERGER (AREN);

$10^{*}, 1$, Curral das Freiras, $600 \mathrm{~m}, 16$. VI.1998, leg. A. AguIAR \& J. Jesus (AMFA). 
Remarks: The first records from Madeira.

It may be assumed that this species has been introduced into Madeira with fruit trees, as it is the case with a number of other species during recent years (AGUTAR \& KARSHOLT, in press).

Ceratobia oxymora (MEYRICK, 1919), comb. nov.

Adult (fig. 4). Wingspan $8 \mathrm{~mm}$; head light brown, thorax and tegulae somewhat darker brownish-grey; forewing fuscous, mottled with yellowish and blackish scales, at $1 / 2$ and at $2 / 3$ in the middle a darker patch; a streak in the same colouration from the basis to $1 /$ 2 below the first patch.

T. oxymora is among the smallest tineid species in Madeira; only Tenaga nigripunctella is also that small, but has different wing markings. However, as very small specimens of some of the other species with fuscous forewings may occur, one can only reach a safe identification by examination of the genitalia.

$0^{*}$-genitalia (fig. 43): Uncus large, acute; arms of gnathos as long as uncus, narrow, pointed apically; valva somewhat longer than uncus, parallel-sided, costal edge somewhat longer, ending bluntly; saccus short. Aedeagus as long as valva; vesica with numerous small spines; cornuti formed as a sclerotized pole and with a spoonlike shaping.

\% -genitalia (fig. 44): the drawing, made from a specimen of the type series, was sent to us through the courtesy of DON DAVIS. Bursa with four spine-shaped signa, as it is typical for the genus.

Bionomy: Early stages unknown. One adult has been collected in a 'bat-cave', and those of a related, undescribed species were collected in a 'bat-cave' in Peru by the second author (D. DAVTs, in litt.).

Beside of the collecting dates there is no information about the behavior of oxymora in Madeira.

Material examined:

10 , Funchal, VIII.1966, leg. E. W. CLASSEY (BMNH);

1\%, Funchal, 20.-31.XII.1969, leg. E. M. CLASSEY (BMNH).

Remarks: The record of this species in Madeira is quite surprising. It seems to be an introduction from the Neotropic.

During a visit by the first author to the National Museum of Natural History (Smithsonian Institution) it was possible to check the neotropic and nearctic Tineidae, too. In this material he found one specimen, collected by DON DAVIS in a 'bat cave on' the Caribian island Antigua. It was determined as "Tinea" oxymora MEYRICK, 1919. A comparison with the specimens from Madeira shows that they belong to the same species.

MEYRICK (1919: 274) described axymora on the basis of 9 specimens from Peru: Chosica, 2800 feet, leg. PARISH. Clarke (1970: 99, pl. 49, fig. 3-3b) published a lectotype of Tinea oxymora.

The size of the genitalia (long arms of the gnathos, valvae with parallel edges) is typical for the genus Ceratobia. The very short saccus of axymora makes it distinguishable from the four other hitherto known members of the genus. It moreover differs from these in 
the wing venation and in having an acute uncus. In this respect it resembles a group of New World taxa (D. DAVIS, in litt.), and it is therefore likely that this species has been introduced to Madeira from the Neotropics.

The fact that the two Madeiran specimens were collected in different years seems to show that axymora is (or has been) breeding in that island. It is a small and inconspicious moth which is easily overlooked, and no attempt has been made to search for it in bats caves in Madeira.

\section{Trichophaga robinsoni nom. n.}

[= Trichophaga abruptella WOLLASTON, 1858, nec THUNBERG, 1794]

Literature records from Madeira:

Tinea abruptella WOLLASTON, 1858: 120.

Trichophaga abruptella (WOLLASTON); WALKER, 1864: 1003; WALSINGHAM, 1894a: 537, 541; WALSINGHAM \& HAMPSON, 1896: 281 (part.); REBEL, 1896: 123; REBEL, 1901: 236; WALSINGHAM, 1908: 1021; REBEL, 1911: 366; REBEL, 1917: 13; COCKERELL, 1923: 247; NORDMAN \& REBEL, 1935: 18; REBEL, 1940b: 8; PETERSEN, 1957: 129 (part.); KLIMESCH, 1980: 95; ROBINSON, 1988: 125-126.

Tinea tapetzella (misidentification); REBEL, 1892: 283; REBEL \& ROGENHOFER, 1894: 17. Trichophaga bipartitella (misidentification); PASSOS DE CARVALHO, 1995: 560, 575 (part.); VIEIRA, 1997: 8 (part.); VIEIRA, 1998: 102.

General distribution:

Canary Islands (Gomera, Grand Canaria, Lanzarote, Tenerife), Morocco (all coll. DEI, ZMUC); Western Sahara (ROBINSON, 1988).

Adult (fig. 5). The Trichophaga species, having forewings with black basal half and white distal half differ from all other Madeiran Lepidoptera. T. robinsoni is characterized by its forewings having a straight costa and a rounded apex; the fringes are whitish apart from a few black scales near the apex (bipartitella has forewings with a slightly convex costa and more pointed apex, and the fringes are dark at distal half with many blackish scales in distal area). Males of the two species can easily be separated on the antennae: those of robinsoni have long cilia (1.0-1.3 X flagellum diameter); in bipartitella the cilia are short (no more than $0.5 \mathrm{X}$ flagellum diameter). For differences to $T$. tapetzella see under that species.

\$-genitalia (fig. 45). Similar to those of bipartitella, but valva broader; the sclerotized part of anellus distinctly larger; moreover aedeagus and saccus are somewhat longer than in bipartitella, whereas uncus is shorter and gnathos more delicate than in abruptella.

q-genitalia (fig. 46). Similar to those of bipartitella, but ostium broadly V-formed, colliculum sclerotized for most of the distance between ostium and ductus seminalis, and ductus bursae more thick-walled.

Bionomy: Probably keratophageous like its congeners. It has been recorded from sea gull pellets (see below).In Madeira locally at the south and east coast. Apparently more common in Porto Santo, and also recorded from Selvagem Grande. Adults come to light throughout the year. 
Material examined:

Lectotype $0^{\star}$, Madeira 1858, leg. T. V. WOLLASTON (BMNH) (published by ROBINSON (1988: 126));

$20^{\star}$ đ゙, Funchal, 19.-20.VII.1962 leg. E. W. CLASSEY (BMNH);

10 , Porto Santo, Feb. 1963, leg. R. UfFEN (BMNH);

10, 1 \%, Selvagem Grande, 23.V.1969, 'ex Sea Gull pellets', leg. G. MAuL (BMNH);

10 , Selvagem Grande, 9.V.1980, leg. M. Serrano (JPC);

10, Porto Santo, Achada de Baixo, 9.X.1981, leg. FERnANDo (JPC);

1ex, Selvagem Grande, 30.X.1984, leg. M. J. Biscoito (MMF);

1 đ. Ponta de São Lourenco, Serra da Picolade, 80 m, 4.VII.1991, leg. M. MEYER (MEY);

20, 2 ㅇ, Ponta de São Lourenco, sea lev., 3.-5.X.1994, leg. O. KARSHOLT (ZMUC);

$100^{*}$, Porto Santo, 23.-24.X.1994, leg. O. Karsholt (ZMUC);

10 , Ponta de São Lourenco, 14.X.1997, leg. B. SkULE (ZMUC).

Remarks: In his paper ROBINSON (1988) separated Trichophaga abruptella (WOLLASTON, 1858) from T. bipartitella (RAGONOT, 1892). However, he apparently overlooked that the former name is a primary homonym of Tinea abruptella (THUNBERG, 1794) (now a synonym of Catoptria falsella ([DENIS \& SCHIFFERMULLER], 1775) in the Pyralidae) (KARSHOLT \& NIELSEN, 1986).

ROBINSON (1988) stated ,abruptella" to be a larger species than "bipartitella" (17-25 mm against 12-23 mm, respectively). Specimens messured by us have a wingspan of 16-35 $\mathrm{mm}$ for abruptella and 11-24 $\mathrm{mm}$ for bipartitella, and the size should therefore be used with care in separating these two species.

The new name is given in honour of Dr. GADEN ROBINSON who first pointed out its specific distinctness.

Trichophaga bipartitella (RAGONOT, 1892)

[= desertella MABILIE, 1907; = amina MEYRICK, 1925]

Literature records from Madeira:

Trichophaga bipartitella (RAGONOT); PASSOS DE CARVALHO, 1995: 560, 575 (part.); VIEIRA, 1997: 8 (part.).

General distribution:

Recorded from the whole Mediterranean area; in Europe northwards to southern France, Italy (Liguria), Rumania and eastwards to Caucasian area; Canary Islands; from Arabian Peninsula (Israel, Jordan, Lebanon, Syria, Saudi Arabia), Somalia and Sudan eastwards to Middle Asia, Mongolia, China. Also recorded from the Azores (VIEIRA, 1997), but it is unclear to which Trichophaga species this record refers.

Adult (fig. 6-7). See under robinsoni. Also similar to $T$. tapetzella by having the colour of the fringes of the forewing dark at distal half with many blackish scales, and the male antennae with short cilia, but tapetzella differs by having a large blackish-brown patch in the middle of the white, distal part of the forewings. The dark form of bipartitella occuring in the Selvages Islands is even more similar to tapetzella, but in bipartitella the outer margin of the dark half of the forewing is transverse (oblique in tapetzella) and the anterior part of thorax white (in tapetzella only the anterior margin is white). 
o-genitalia (fig. 47). See under robinsoni.

I-genitalia (fig. 48). Similar to those of robinsoni, but ostium broadly U-formed, colliculum sclerotized for less than half of the distance between ostium and ductus seminalis, and ductus bursae very thin-walled.

Bionomy: Keratophageous; larvae recorded from raptor pellets, weathered carnivore faeces and mammal hides (ROBINSON, 1988).

There is no data on the behavior of bipartitella in the Madeira Islands, apart from the label data of the two examined specimens.

Material examined:

$1 \sigma^{*}$, Selvagem Grande, 9.V.1980, leg. M. SERRANO (JPC);

$10^{\circ}$, Selvagem Grande, 19.IX.1987, leg. F. ZINO (MMF).

PASSOS DE CARVALHO (1995: 560, 575) recorded bipartitella (with abruptella WOLLASTON as a synonym) from Selvagem Grande, 9.VI.1980. The date may be due to a misprint, as the two specimens from Selvagem Grande, kindly loaned to us by PASSOS DE CARVALHO, are labeled as caught at 9.V.1980. Strangely enough these two specimens include one specimen of abruptella and one of bipartitella. The record by VIEIRA (1997: 8) is based on that of PASSOS DE CARVALHO.

Trichophaga tapetzella (LINNAEUS, 1758)

[= tapezella FABRICIUS, 1794; = pulchella FABRICIUS, 1794; = taperana FABRICIUS, 1798; = pulchana FABRICIUS, 1798; = tapetiella ZELLER, 1839; = palaestrica BUTLER, 1877]

General distribution:

Recorded from all European countries (except Portugal); Algeria; Canary Islands; Lebanon; Turkey; Russia (European part, Caucasian area); introduced into North and South America, Australia, and New Zealand.

Adult (fig. 8). T. tapetzella is similar to robinsoni, but differs in having the border between the dark and the white part of the forewing oblique, and the colour of the fringes dark at distal half with many blackish scales, and by the short ciliae at the male antenna (no more than $0.5 \mathrm{X}$ flagellum diameter). For differences to bipartitella see under that species.

$\sigma^{7}$-genitalia (fig. 49-50).

P-genitalia (fig. 51).

Bionomy: The larva feeds on hair, wool and feather, and can be bred from birds nests. It is more common in outhouses and stables than in houses. For description of the larva and for more detailed information see by HINTON (1956).

There are no details about the early stages of tapetzella in Madeira. Adults have been collected infrequently from April to October, mostly in the town of Funchal, but also inland up to $600 \mathrm{~m}$.

Material examined:

$20^{*}$, Funchal-Lido, 15.-17.IX.1973, leg. N. L. WoLfF (ZMUC)

1 +, Funchal-Lido, 25.VIII.1974, leg. E. TRAUGOTT-OLSEN (ZMUC); 
$10^{\star}$, Serra d'Água, Pousada dos Vinhaticos, 650 m, 8.VI.1976, leg. N. L. WOLFF (ZMUC); 1 †, Fajã da Noguiera, 600 m, 14.-15.IX.1977, leg. LOMHOLDT \& WOLFF (ZMUC); 10 , Ponta de São Lourenco, sea lev., 26.VI.1993, leg. O. KARSHOLT (ZMUC); 1 ㅇ, Porto Moniz, sea lev., 4.VII.1993, leg. O. KARSHOLT (ZMUC); 20, Funchal, 3., 16. IX. 1994, leg. M. \& E. ARENBERGER (AREN); 20, Porto Santo, 13.-15.IV.1996, leg. O. KARSHOLT (ZMUC); 10 , Funchal, $50 \mathrm{~m}$, 20.-26.X.1997, leg. D. NILSSON (ZMUC).

First records from Madeira, as the records given by REBEL (1892: 283) and REBEL \& ROGENHOFER (1894: 17) are based upon misidentifications [of robinsoni] (REBEL, 1896: 123). T. tapetzella is probably a tather recently introduced species in Madeira.

Praeacedes atomosella (WALKER, 1863)

[= seminolella BEUTENMULLER, 1889; = thecophora WALSINGHAM, 1908; = despecta MEYRTCK, 1919; = deluccae AMSEL, 1955; = malgassica GOZMÁNY, 1970; = decui CAPPUṢE \& GEORGESCU, 1977]

Literature records from Madeira:

Niditinea spretella (misidentification); BRADLEY, 1958: 197; GARDNER \& CLASSEY, 1959: 204.

Praeacedes thecophora (WALSINGHAM); PETERSEN \& GAEDIKE, 1979: 404.

Praeacedes atomosella (WALKER); PASSOS DE CARVALHO, 1995: 575; VIEIRA, 1997: 7; VIEIRA, 1998: 102.

General distribution:

Pantropical (ROBINSON \& NiELSEN, 1989). Palaearctic region including the Canary Islands; Azores; Malta; Cyprus; Egypt.

Adult (fig. 9). This species has the forewings covered with yellowish and blackish brown scales, and two black patches in the fold and at $3 / 4$. It is very similar to Niditinea fuscella (LINNAEUS) but in atomosella the light and dark scales of the forewings are more evenly disturbed. Bred specimens can be recognized from the characteristic larva case (fig. 29). Only Phaereoeca allutella (REBEL) makes a similar case, but in that species the antennae are longer than the forewing.

$0^{\lambda}$-genitalia (fig. 52-53).

q-genitalia (fig. 54-55).

Bionomy: The larvae feed from a characteristic flattened, elongate oval case composed of fibers and detritus and lined with silk (fig. 29). It is similar to that of Phaereoeca allutella (REBEL) but in average smaller and more rounded at proximal end. The cases can be found at house walls. Its feeding habit is not known with certainty, but probably it is chitinophagous like that of $P$. allutella (ROBINSON \& NIELSEN, 1993: 142; O. KARSHOLT, pers. observ.). A detailed description of the larva is given by HINTON \& BRADLEY (1956) under the name Titaenoses thecophora.

In Madeira atomosella has been found in Funchal and some other costal towns. Most adults have been collected through the winter half-year. It is less common than allutella, but in Porto Santo atomosella is the commoner one of these two species. 
Material examined:

10, Funchal, Museum Garden, 14.II.1953, leg. ?, 'Niditinea spretella SCHIFF., det. J. D. BRADLEY, 1958' (MMF);

1 i , Lombo Jamboeiro, São Roque, III.1953, leg. A. FIGUEIRA, 'Niditinea spretella SCHIFF., det. J. D. BRADLEY, 1958' (MMF);

10 , Funchal, 7. - 22. XII. 1957, leg. E. W. CIASSEY (BMNH);

10 , Funchal, 15.VI.1972, leg. H. ENGHOFF (ZMUC);

$20^{\circ}, 2$, Funchal, la./pup. ult.IX.1972, leg. LUNDQVIST \& WOLFF (ZMUC);

10 , Funchal, 20.IV.1974, leg. M. MÜNSTER-SVENDSEN (ZMUC);

10, Funchal, Lido, 18. - 22. VIII. 1974, leg. N. L. WOLFF (ZMUC);

10 , Funchal, $50 \mathrm{~m}$, 17.II.1979, leg. O. KarSHOLT (ZMUC);

1 \% , Funchal, 10 m, la. 18.II.1979, leg. O. KARSHOLT (ZMUC);

1 \%, Funchal, 15.IX.1980, leg. PASSOS DE CARVALHO \& LuIS DE CAMOES (JPC);

10 , Porto Moniz, 7.III.1994, leg. P. DE BJøRN \& J. DAMGAARD (ZMUC);

10 , Porto Santo, 12.III.1994, leg. P. DE BJørN \& J. DAMGAARd (ZMUC);

10 , Porto Santo, pup. 23.X.1994, leg. O. Karsholt (ZMUC);

10 , Porto Santo, 24.X.1994, leg. O. Karsholt (ZMUC);

19 , Porto Santo, 12.IV.1996, leg. O. Karsholt (ZMUC);

10 , Funchal Lido, 50 m, 18.IX.1997, leg. O. KARSHOLT (ZMUC);

10 , Amparo, São Martinho, 3.X.1998, leg. J. JESUS (AMFA).

Remarks: P. atomosella is a relatively new species in the Madeiran Lepidoptera fauna. Its conspicious larva case is now common in Funchal and it is unlikely that it was overlooked by lepidopterists visiting the island earlier.

Tineola bisselliella (HUMMEL, 1823)

[= flanifrontolla THUNBERG, 1794, nec DENIS \& SCHIFFERNULLLER, 1775; = destructorSTEPHENS, 1825;

= crinella SODOFFSKY, 1830; = lanariella CLENENS, 1859; = furriferella ZAGULAJEV, 1954; = anaphecola GOZMÁNY, 1967]

Literature records from Madeira:

Tineola bisselliella (HUMMEL); WALSINGHAM, 1894a: 537, 542 (part.); WALSINGHAM, 1908: 1026; ReBEL, 1917: 13; REBEL, 1940b: 8; PASSOS DE CARVALHO, 1995: 575.

General distribution:

Known from the whole Palearctic region, introduced in other regions too.

Adult (fig. 10). T. bisselliella can be recognized by its pale ochreous forewings, without darker markings. However, some specimens of T. murariella (especially worn ones) can be very similar.

o-genitalia (fig. 56-57).

o-genitalia (fig. 58-59).

Bionomy: The larva is a wellknown pest of wool and other animal fibres, but it can also feed on a variety of other materials. For description of the larva and for detailed information see HINTON (1956). 
Nothing is known about the habit of bisselliella in Madeira. The only authentic specimen was collected around 1850, and we have seen no evidence that it should still occur there.

Material examined:

$10^{7}$, 'Madeira, [leg. Wollaston], B.-BAKer coll. 13594 / Tineola bisselliella HML., WALS. Tr. Ent. Soc. Lond. 1894.572, Named by WALS. / BM 9 genitalia slide 13328' (BMNH).

Remarks: WALSINGHAM (1894a: 542) listed 4 specimens from Madeira. At least one of these belongs to bisselliella, and it is the only confirmed record from Madeira for this wellknown pest. Another of the specimens recorded by WALSINGHAM (op cit.) proved to belong to Tinea murariella (see below).

Tinea murariella STAUDINGER, 1859

[= bipunctella RAGONOT, 1874]

Literature records from Madeira:

Tineola bipunctella RAGONOT; REBEL, 1940b: 8; REBEL, 1940c: 10, 47, 57, 59, pl. II, fig. 9. Tinea murariella STAUDINGER; ROBINSON, 1979: 85, 123; PASSOS DE CARVALHO, 1995: 575; VIEIRA, 1997: 9; VIEIRA, 1998: 102;

Tineola bisselliella (misidentification, part.); WALSINGHAM, 1894a: 537, 542.

General distribution:

Palearctic region: The whole Mediterranean region (no records from the Balkan Peninsula and from Greece (except Rhodos Island)); Azores, Canary Islands, Great Britain, Rumania, Israel, Saudi Arabia, Caucasus area (Batumi). Neotropic region: Venezuela, Argentina, Brazil. A distribution map was published by ROBINSON (1979: 123).

Adult (fig. 11). T. murariella can be recognized by its ochreous forewings, with a blackish spot at 3/4 and sometimes one or two smaller such spots in the fold. It resembles T. bisselliella, who lacks black markings in the forewing.

$0^{\star}$-genitalia (fig. 60-61).

o+-genitalia (fig. 66-67).

Bionomy: Larvae on fur, woolen clothing, hides, hooves and insect specimens, taptor pellets. The species appears able to utilize much the same range of foodstuffs as the other species of the pellionella-complex of the genus. For a more detailed compilation of all hitherto known biological dates see ROBINSON (1979).

In Madeira a specimen was bred from a case (fig. 30) found on a wall in February, and in Deserta Grande a case was dug up from the earth together with a newly emerged specimen. Adults have been collected singly in costal localities, mostly in the winter half-year.

Material examined (the records were noted only on the basis of material, which is identified by genitalia dissection. This is necessary for separating murariella from the other species of the pellionella-group):

1오. 'Madeira, [leg. WOLLASTON], B.-BAKER Coll. 13595 / WALS. coll. / Tinea bipunctella

RAG. O' $\sigma^{\prime}(\mathrm{BMNH})$;

1ㅇ, Funchal, 1.-8.V.1938, leg. STORA (ZMUH); 
$10^{\circ}$, Madeira Isl., Deserta Grande, 22.IV.1974, leg: WOLfF (ZMUC);

10 , Funchal, 25.IX.1976, leg. L. $\AA$. JANZON (ZMUC);

10 , Funchal, la. 23.II.1979, leg. O. KARSHOLT (ZMUC);

10, Santa Cruz, ca. 25 m, 24.II.1979, leg. O. KARSHOLT (ZMUC);

10, Madeira Isl., Deserta Grande, 14.IV.1980 (JCP);

10 , Madeira Isl., Porto Santo, 24.X.1994, leg. O. KARsholT (ZMUC);

19, Amparo, São Martinho, 3.X.1998, leg. J. JEsUs (AMFA).

Tinea dubiella STAINTON, 1859

[= turicensis MULLER-RUTZ, 1920; = bispinella ZAGUL_AJEV, 1960; = tenerifi ZAGULAJEV, 1966]

Literature records from Madeira:

Tinea pellionella (misidentification): STAINTON, 1859: 212; REBEL, 1892: 283; REBEL \& ROGENHOFER, 1894: 17; WALSINGHAM, 1894a: 537, 541; REBEL, 1901: 238; WALSINGHAM, 1908: 1025; REBEL, 1911: 366; REBEL, 1917: 13; NORDMAN \& REBEL, 1935: 18; Rebel, 1940b: 8; PAssos de CARVAlHO, 1995: 575; VIEIRA, 1997: 9; VIEIRA, 1998: 102. Tinea dubiella STAINTON; ROBINSON, 1979: 88-91, 108, 124.

General distribution:

In Europe from Spain northwards to Great Britain, Denmark and Sweden, eastwards through France and Italy (including Sicily) to Rumania and the European part of Russia; in northern Africa from Morocco and Algeria and from the Canary Islands. Also recorded from St Helena, South Africa, Sikkim, Australia, New Zealand and U.S.A. A distribution map was published by RoBINSON (1979: 124).

Adult (fig. 12). T. dubiella has fuscous forewings, mottled with yellowish scales and with three blackish spots. The antennae are shorter than the forewings (opposite to allutella). It is (normally) larger than C. oxymora, and the black spots are more prominent than in $P$. atomosella.

$0^{7}$-genitalia (fig. 62-64).

\&-genitalia (fig. 68-69).

Bionomy: The species appears able to utilize much the same range of foodstuffs as the other species of the pellionella-complex of the genus. Larvae have been found in damp carpet lining a disused dog-kennel, on pellets of several birds, in swallows' nests etc. For a more detailed information see ROBINSON (1979).

In Madeira only found in few specimens, mostly about a century ago.

Material examined (concerning the used records see remarks under T. murariella):

1 o, 'Madeira, 1858, Wollaston, B.M. 1858-21 / Tinea pellionella L., Ann. Mag. N.H. (35), III: 212 no 1311 (1859), [Southern] Desertas, Topotype, Mader. XXI, HD / BM Slide $13182 \sigma^{\prime}$ (BMNH);

$10^{\circ}$, 'Madeira, [leg. WOLlaston], B-BAKer coll., WAis. coll. / BM slide 13329' (BMNH); 10 , Machico, 23.IV.1904, leg. EATON / 'Tinea pellionella, named by DuRRANT' (BMNH); 10 , Serra d'Água, Pousada dos Vinhaticos, 650 m, 15.-16.VI.1976, leg. N. L. WolfF (ZMUC). 
Remarks: The records in literature listed above all refer to the few specimens found before 1904 by British entomologists, and recorded under the name of T. pellionella LINNAEUS. They were examined by ROBINSON (1979: 88-91) who stated that they belong to dubiella. T. pellionella is removed from the list of Madeiran Lepidoptera until its occurence there is confirmed.

Tinea trinotella THUNBERG, 1794

[= ganomella TREITSCHKE, 1833; = lapella auct.; = tripunctella auct.]

Literature records from Madeira:

Tinea trinotella THUNBERG; PASSOS DE CARVALHO, 1995: 561, 575.

General distribution:

Recorded from all of Europe: eastwards to the European part of Russia, northwards to the entire Scandinavian Peninsula, the entire European part of the Mediterranean area; further records exist from Turkey, Algeria and from the Canary Islands.

Adult (fig. 13). Characterized by its light yellowish forewings, which are more or less overlaid with grey and black, especially along costa and dorsum, and in the apical part; a distinct black spot in middle of dorsal part of the forewing.

ơ-genitalia (fig. 65).

$q$-genitalia (fig. 70).

Bionomy: Larvae are known from nests of many bird species. For description of the larva and for more detailed information see HINTON (1956) under the name Acedes ganomella.

In Madeira found singly, mostly in laurisilva localities between 600 and $1050 \mathrm{~m}$ during summer months.

Material examined:

10 $0^{*}$ Pousada, Serra d'Água, 660 m, 31.VIII.1975, leg. N. L. WOLFF (ZMUC);

1ㅇ, Queidemas, 2.VI.1980, leg. J. PASSOS DE CARVAL Ho (JPC);

1 ㅇ, Rabaçal, 24.VI.1982, leg. J. PASSOS DE CARVALHO (JPC);

1 ㅇ, SW Porto do Moniz, Santa Madalena, Pico Alto, 600 m, 9.VII.1991, leg: M. MEYER (MEY);

1 ㅇ, N. Pto Encumeada, Lamaceiros, 900 m, 11.VII.1991, leg. M. MEYER (ZMUC).

PASSOS DE CARVALHO (1995: 561) also recorded trinotella from Fajã da Nogueira.

Remarks: The specimens from Madeira and the Canary Islands differ in the wing patterns from typical specimens. The structures of the genitalia show no indications for separating these specimens from the typical form of that species. For an account of the Macatonesian form see REBEL (1906: 40) and KLIMESCH (1980: 98). 
Niditinea fuscella (LINNAEUS, 1758)

[= spretella DENIS \& SCHIFFERMULLER, 1775; = crinitella SCHRANK, 1802; = fuscipunctella HAWORTH, 1828; = nubilipennella CLENENS, 1859; = abligatella WALKER, 1863; = frigidella PACKARD, 1867; = griseella CHAMBERS, 1873; = eurinella ZAGULAJEY, 1952; = distans GOZMÁNY, 1959]

Literature records from Madeira:

Tinea fuscipunctella HAWORTH; WALSINGHAM, 1908: 1024; REBEL, 1911: 366; REBEL, 1917 : 13; Cockerell, 1923: 247; Riley, 1923: 286; ReBel, 1940b: 8; ReBeL, 1940c: 10, 46, 57.

Niditinea fuscella (Linnaeus); Passos DE CARVAlHo, 1995: 575; VIEIRA, 1997: 9; VIEIRA, 1998: 102

General distribution:

Known from nearly whole Palearctic region, from Mediterranean area eastwatds to Japan.

Adult (fig. 14). Forewings with light yellowish ground colour, which is more or less covered with black scales; 2-3 indistinct, black spots. Very similar to P. atomosella (see under that species).

o-genitalia (fig. 73-74). On fig. 75: sclerotization of the last sternit.

o -genitalia (fig. 71-72).

Bionomy: Larvae were found in bird-nests, feeding on feathers and hair. For description of the larva and for more detailed information see HINTON (1956) under the name Acedes fuscipunctella.

In Madeira found in few specimens in towns at the south coast during the winter halfyear.

- Material examined:

1 ․ 'Madeira, [leg. WOLLASTON], B.-BAKer Coll. 13581 / BM o genit. 13330' (BMNH);

10, Funchal, Jan.1930, leg. CROKCELL (BMNH);

$10^{\star}$, Funchal, 1.III.1931, leg. CROKCELL (BMNH);

10 $0^{\star}$, Caniço, 12.-18.IX.1977, leg. LOMHOLDT \& WOLFF (ZMUC);

20, Funchal Lido, 50 m, 14.-16.IX.1997, leg. O. KARSHOLT (ZMUC).

Remarks: The record by BRADLEY (1958: 197) (as Niditinea spretella SCHIFFERMÜLLER) refers to P. atomosella (K. TUCK, in litt.).

\section{Phaereoeca allutella (REBEL, 1892)}

[= verna MEYRICK, 1924]

Literature records from Madeira:

Tineola allutella REBEL; WALSINGHAM, 1894a: 537, 542; REBEL, 1896: 125; REBEL, 1901: 240; Walsinghan, 1908: 1026; ReBel, 1917: 13; Rebel, 1940b: 8; PAssos DE CARVALHO, 1995: 561, 575.

Phaereoeca allutella (REBEL); Petersen, 1957: 342; Klimesch, 1980: 99; BÁEZ, 1998: 176. 
General distribution:

In the Palearctic region known only from the Canary Islands and from Madeira. Other records are from the Etiopian, Australian and Oriental regions.

Adult (fig. 15). This somewhat uncharacteristic species can be separated from similar Madeiran tineids like P. atomosella, N. fuscella and T. dubiella by having the antennae longer than the forewings.

$0^{7}$-genitalia (fig. 76-79).

o-genitalia (fig. 80).

Bionomy: The larvae feed from a characteristic flattened, broadly spindle-shaped case composed mainly of grit with fragments of detritus. The case is similar to that of Praecedes atomosella but on average larger and more pointed at proximal end (fig. 31). The cases can be found at house walls. The larva probably feeds on chitin in the form of dry insect remains (ROBINSON \& NIELSEN, 1993: 152-53; OK, pers. observ.). A detailed description of the larva is given by HINTON \& BRADLEY (1956).

In Madeira allutella is found commonly along the central part of the south coast, and there are few records from other parts of the island and from Porto Santo. Most adults have been found during the summer half-year (opposite to atomosella). ROBINSON \& NiELSEN (1993: 152) suggested allutella (and other members of Phereoeca) to be ,immune to light-traps". However, the second author collected several specimens in light-traps with 8 Watt actinic tubes.

Material examined:

10 , Madeira, leg. T. V. WOLLASTON (BMNH);

4\%, Funchal Lido, ex la. ultimo XI.1972, leg. LUNDQVIST \& WOLFF (ZMUC);

10 , 1 \% Funchal Lido, sea lev., la. 14.X.1973, leg. N.L. WOLFF (ZMUC);

$110^{7}$, Funchal Lido, 24.-26.VIII.1974, leg. N. L. WOLFF (ZMUC);

$10^{\star}$, Funchal Lido, 11.VI.1976, leg. N.L. WOLFF (ZMUC);

$10^{\circ}$, Serra d'Água, Pousada dos Vinhaticos, 600 m, 16.VIII.1974, leg. N. L. WOLFF (ZMUC);

10, Madeira, 13.-19.XI.1977, leg. H. K. JENSEN (ZMUC);

$50^{\star}$, Ponta do Sol, sea lev., 12.VI.-2.VII.1993, leg. O. KARSHOLT (ZMUC);

$10^{\circ}$, Machico, sea lev., 23.VI.1993, leg. O. Karsholt (ZMUC);

10 , Funchal, 16.IX.1994, leg. M. \& E. ARENBERGER (AREN);

20, Porto Moniz, sea lev., 13.X.1994, leg. O. KARSHOLT (ZMUC);

$50^{\circ}$, Ponta do Sol, sea lev, 16.X.1994, leg. O. Karsholt (ZMUC);

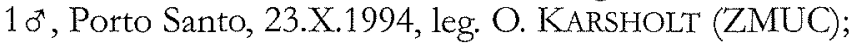

8, Santa Cruz, sea lev., la. 25.X.1994, leg. O. KARSHOLT (ZMUC).

Remarks: Apart from a specimen in WOLLASTON's material collected around 1850 most records are from recent years. The species' occurence in Madeira is probably due to introduction by man. 
Monopis crocicapitella (CLEMENS, 1859)

[= amandatella WALKER, 1863; = byalinella STAUDINGER, 1870; = lombardica HERING, 1889; = heringi RICHARDSON, 1893; = ptilophaga ENDERLEIN, 1909; = prometopias GYEN, 1913; = cecconii TURATT, 1919; = dobrogica GEORGESCU, 1964]

Literature records from Madeira:

Monopis crocicapitella (CLEMENS); BRADLEY, 1958: 197; GARDNER \& CLASSEY, 1959: 204; PASSOS DE CARVALHO, 1995: 560, 575; VIEIRA, 1997: 8; VIEIRA, 1998: 102.

General distribution:

From the Iberian Peninsula through out all of Middle and South Europe eastwards to Japan; also recorded from the Canary Islands, Azores and from Morocco; North America.

Adult (fig. 16). This rather small species is easily recognized by its blackish forewings, mottled with yellowish scales, by the conspicious hyaline spot, and by having the dorsum yellow.

$0^{*}$-genitalia (fig. 81-82).

o+-genitalia (fig. 86-87).

Bionomy: Larvae on clothes, in dried seeds and in other dried plant material, in bird nests, too. For more detailed information see HINTON (1956).

In Madeira found along the coasts and at lower elevations in the highland during the summer half-year.

Material examined:

$10^{*}$, Lombo Jamboeiro, São Roque, 10.IV.1953, leg. A. FIgUEIRA (MMF);

1 ex Palheiro Fairendo, 16.XII.1957, leg. CLASSEY \& GARDENER (BMNH);

$10^{\star}$, Pousada dos Vihaticos, Serra d’Água, 600 m, 15.-16.VIII.1974, leg. N. L. WolfF (ZMUC);

$10^{*}$, Cabo Girao, 400 m, 25.V.1989, leg. M. Hellers (MMY);

19, Chão da Ribeira, 430 m, 14.VII.1991, leg. M. MEYer (MMY);

10 , Ponta do Sol, sea lev., 12.VI.1993, leg. O. KARSHOLT (ZMUC);

$1 \sigma^{*}$, Machico, sea lev, 14.VII.1993, leg. O. KARSHOLT (ZMUC);

20", Funchal, 5.-10.V.; 18.IX.1994, leg. M. \& E. ARENBERGER (AREN);

$10^{*}$, Porto Moniz, sea lev., 9.X.1994, leg. O. KARSHOLt (ZMUC);

10 , Ponta do Sol, sea level, 16.X.1994, leg. O. KarsholT;

10 , Porto Santo, 23.X.1994, leg. O. KARSHOLT (ZMUC);

$10 \%$ Machico, sea lev, .25.X.1994, leg. O. KARSHOLT (ZMUC);

$2{ }^{\circ}$, Porto Santo, 14.-15.IV.1996, leg. O. KARSHOLT (ZMUC);

$10^{*}$, Ponta de São Lourenco, 14.X.1997, leg. B. SKULE (ZMUC);

10 , Funchal, 50 m, 20.-26.X.1997, leg. D. NiLSSON (ZMUC).

PAssos De CARVAlHo (1995: 560) also recorded crocicapitella from Fajã da Nogueira, João Frino and Santa.

Remarks: $M$. crocicapitella is probably a rather recent introduction in Madeira. 


\section{Monopis nigricantella (MILLIËRE, 1872)}

Records in literature:

Monopis nigricantella (Millière) HANNEMLANn, 1977: 237; PETERSEN \& GAEdiKe, 1979 : 409; PASSOS DE CARVALHO, 1995: 575; VIEIRA, 1997: 8; VIEIRA, 1998: 102.

Monopis lavigella ([DENIS \& SCHIFFERMÜLLER] (misidentification); PASSOS DE CARVALHO, 1995: 560, 575.

Monopis imella (HÜBNER) (misidentification); PASSOS DE CARVALHO, 1995: 575; VIEIRA, 1997: 8; VIEIRA, 1998: 102.

General distribution:

Recorded from northern Africa (Morocco, Tunisia, Algeria), from the Canary Islands and the Azores, and from Spain, France, Italy and Sardinia.

Adult (fig. 17). M. nigricantella is characterized by its yellow head, and by its blackish brown forewings, with scattered yellowish scales, and a small hyaline spot.

o -genitalia (fig. 83-85).

o-genitalia (fig. 88-89).

Bionomy: There is no information about the biology of the larvae.

$M$. nigricantella has been found all over Madeira and in Porto Santo from sea level to the mountains, and throughout the year.

Material examined:

10 , Somada, 23.III.1965, leg. PINKER;

$10^{\star}$, Funchal Lido, 11.VI.1976, leg. N. L. WOLFF (ZMUC);

10, Fajã de Noguiera, 600 m, 14.-15.IX.1977, leg. LOMHOLDT \& WOLFF (ZMUC);

10, Funchal, 50 m, 20.II.1979, leg. O. KARSHOLT (ZMUC);

$10^{\circ}$, Curral das Freiras, $650 \mathrm{~m}, 13 . \mathrm{V} .1989$, leg. M. Helders (MMY);

10 , Cabo Girao, 400 m, 25.V.1989, leg. M. HeLlers (MMY);

10, Encumeada, 1000 m, 18.VI.1993, leg. O. KARSHOLT (ZMUC);

10, Porto Moniz, sea lev., 7.VII.1993, leg. O. KARsholT (ZMUC);

30, Fajã de Noguiera, 600-800 m, 31.VIII., 11.IX.1994, leg. M. \& E. ArENBERGER (AREN);

1 đ. Fajã de Nogueira, 600-1000 m, 8.X.1994, leg. O. KARSHOLT (ZMUC);

60, Porto Santo, 23.-24.X.1994, leg. O. Karsholt (ZMUC);

7\%, 2 \% , Porto Santo, 13.-14.IV.1996, leg. O. Karsholt (ZMUC);

10 , below Pico Areio, $1600 \mathrm{~m}, 10 .-11.1 X .1997$, leg. O. KARSHOLT (ZMUC);

40 , Curral das Freiras, 850 m, 21.IX.1997, leg. O. KARSHOLT (ZMUC);

10, Funchal, 50 m, 20.-26.X.1997, leg. D. NILSSON (ZMUC);

$10,13 \mathrm{~km}$ NW Funchal, Eira do Serrado, $1100 \mathrm{~m}, 22 .-25 . X .1997$, leg. D. NILSSON (ZMUC).

Remarks: PASSOS DE CARVALHO (1995: 560, 575) lists four species of Monopis from Madeira. Beside of crocicapitella, for which he gives locality and date of capture, and which we consider correctly identified, these are: imella, laevigella and nigricantella. He only gives exact locality and date for laevigella, whereas the two others are listed without further information (For details on PASSOS DE CARVALHO's paper see KARSHOLT (2000)). 
M. nigricantella is closely allied to imella and they are often mixed in collections. We have seen no correctly identified specimens of imella from Madeira, and we presume that its presence in the list by PASSOS DE CARVALHO is due to confusion with the common nigricantella. We have had no opportunity to study the specimens (from João Frino and Curral das Freiras), on which PASSOS DE CARVALHO listed laevigella from Madeira, but as he gives no records of nigricantella we consider it likely that he misidentified his specimens of these two rather similar species.

Judging from the examined material nigricantella seems to be a relatively new inhabitant in the Madeiran Lepidoptera fauna, and it has become more common in recent years.

\section{Monopis henderickxi sp. n.}

Material examined: 9 males, 9 females:

* Holotype, [+ case + exuvia] Madeira, Serra do Rosario, $600 \mathrm{~m}$, case collected 12.I.1996 (humid forest), ex 1. 18.III.1996, leg. H. A. HENDERICKX, gen. slide R. GAEDIKE No. 4813 (HEN); Paratypes: 20 , same locality and same date for case collecting, ex 1. 24.III.1996; 1 \&, ditto, ex 1. 31.III.1996; 1 o [+ case + exuvia], ditto, ex 1.1.IV.1996; 1 \%, ditto, ex 1. 24.IV. 1996; 3 9 [1 specimen, gen. slide R. GAEDIKE No. 4815 + case + exuvia], ditto, ex 1. 9.IV. 1996; 1 9 [ case + exuvia], ditto, ex 1. 3.IV.1996, gen. slide H. HENDERICKX No. 218; 1 \& [+ case + exuria], ditto, ex 1. 6.IV.1996; 1 q, same locality and same date for case collecting, ex 1. 7.V.1996; 1 \% [+ case + exuvia], ditto, ex 1 . 22.III.1996; 1 o [+ case + exuvia], Madeira, Pico Ruivo, $1400 \mathrm{~m}$, case collected 17.I.1996 (rocks/low veg.), ex 1. 7.III.1996, leg. H. A. HENDERICKX (HEN, DEI), gen. slide H. HENDERICKX No. 216; $1 \sigma^{*}$, Achada do Teixeira, 1600 m, 22.VI.1993, leg. O. KarSHOLT (ZMUC); $30^{*}$, Madeira, Paul da Serra, 6.VII.1993, leg. O. KARsholT (DEI, ZMUC).

Adult (figs 18-19). Wingspan 8-10 mm; vertex yellow-brown, palpi lighter, antennae dark brown, as long as the forewings; thorax and tegulae deeply dark-brown; forewings dark brown, at costa with some (7-9) short, narrow, pale, nearly white streakes, oblique to apex, at beginning of cilia a larger white streak, nearly reached by one of the oblique costal streakes; some smaller white dotes on cilia to apex; the white streaks longer in the first third of the wing, extended to dorsum, interrupted in the middle; the hyaline spot overlaid with scales; some specimens with more lighter scales; hindwings grey.

\%-genitalia (fig. 92-94): Uncus typical for the genus, arms of gnathos basically broad, pointed apically, somewhat variable on the tip (fig. 94); saccus long, narrow, ending rounded; valva parallel-sided, bent in middle of costal edge, transtilla well developed, with rounded point. Aedeagus longer than saccus, vesica with numerous very small pointed and rounded spines.

o-genitalia (fig. 95-96): Apophysae forked; ostium broad cup-shaped, with fine-grained structure; ductus bursae in the first third more strongly sclerotized; bursa with some (810) small pointed signa.

Bionomy: The larvae live in more or less cylindrical cases and seem to be lichenophagous. This case is also the cocoon for the pupae (fig. 32). At Serra do Rosario $(600 \mathrm{~m}$ ) the cases were located on tree trunks in a very humid laurisilva, between cracks in the bark. The cases found below Pico Ruivo $(1400 \mathrm{~m})$ were situated under stones and rocks. The specimens from Achada do Teixeira and Paul da Serra were collected in early afternoon sunshine among grass growing between rocks, using a sweeping net and a bee smoker, respectively. 
Remarks: $M$. benderickexi is clearly distinguished from the hitherto known members of Monopis (apart from the much larger barbarosi) by lacking a visible hyaline dot. The male genitalia (aedeagus without clearly developed cornuti) are also different from all other species of the genus with unicolourous forewings. In the female genitalia the shape of the ostium and of the signa are clearly different from the other members of the genus.

The studied specimens show some variation in the white markings in the forewings. The few specimens bred from below Pico Ruivo have a more fuzzy wing pattern than those from Serra do Rosario, and the specimen from Achada do Teixeira has a distinct white, transverse band at $2 / 3$ of the forewing. Because of its small size, long antennae and its characteristic wing markings $M$. benderickxi should not be mistaken for other species of Madeiran Lepidoptera.

The new species is named in honour to Mr. HANS HENDERICKX, who was able to rear it from larvae for the first time.

\section{Monopis barbarosi (KOCAK, 1981), comb. nov. [= irrorella WOLLASTON, 1858, nec HÜBNER, 1796]}

Literature records from Madeira:

Tinea irrorella WOLLASTON, 1858: 120; WALKER, 1864: 1002; WALSINGHAN, 1894a: 537, 542; ReBEL, 1901: 239; REBEL, 1917: 13; REBEL, 1940b: 8; PASSOS DE CARVALHO, 1995: 575.

Reisserita irrorella (WOLLASTON); PETERSEN, 1957: 114.

Reisserita barbarosi KOÇAK, 1981: 111.

Adult (fig. 20). Wingspan $16 \mathrm{~mm}$. Head orange-brown; antenna long, reaching apex of forewing, brown; thorax yellowish; tegula brown. Forewing brownish, with small spots of whitish yellow scales scattered over the wing; no visible hyaline spot. Hindwing unicolourous light grey-brown, with a slight golden shade.

The relatively large size, the long antennae, and the brown forewings, without a hyaline spot, but with irrorated whitish yellow scales separate barbarossi from other Madeiran Tineidae.

o-genitalia: unknown.

P-genitalia (fig. 90-91): apophysae not forked, very long; ostium with two rounded corners bearing setae; the first part of ductus bursae with lengthwise folds; in the bursa a lot (appr. 20) of small mostly triangular spines.

Bionomy: Early stages unknown. WOLLASTON gave no details about where or when he collected the holotype.

Material examined:

Holotype + , „XX / Madeira 1858 / WOLLASTON, B.M. 1858-21 / Tinea irrorella WISTN., Ann. Mag. N.H. (3) 1: 120 (1858), Madeira, Type XIX HD / BM \& Genitalia slide No 4527“ (BMNH). 
Remarks: KOÇAK (1981) erroneously placed this species into the genus Reisserita (probably based on PETERSEN (1957: 114)). Without doubt it belongs in the genus Monopis; the evidence for this opinion is the presence of a (scale covered) hyaline spot in the forewing and the structure of the genitalia.

$M$. barbarosi differs from other Palearctic species of Monopis, and it also does not belong to any New World species of this genus, including $M$. irrorella DIETZ, 1905, a synonym of $M$. marginistrigella (CHAMBERS, 1873) (D. R. DAVIS, in litt.). It is atypical for Monopis in having broader forewings with unmodified venation, with exeption of M3 and CuA1 being connate ( $G$. ROBINSON, in litt.).

There is hitherto known only the female holotype from Madeira. The recent studied material contained no specimens, which could be refered to this species. All of the eight literature records mentioned above refer to the same specimen.

WAISINGHAM (1894a: 537, 542) recorded under 'Tinea sp.' four specimens from Madeita, also from WOLLASTONs material: 'These are closely allied to irrorella, WLSTN., but differ in having smaller and more scattered markings and no apical spot [sic! - there is no apical spot in the forewings of the holotype of irrorella]; they are not in good enough condition for description'. We have been unable to trace these specimens in the collection of the BMNH, and GADEN ROBINSON of that museum stated (in litt. to N. L. WOLFF) that they could not be found. The description given by WALSINGHAM does not fit any species of Tineidae from Madeira, and whitout being able to study these specimens we can give no guess about their identity. However, considering that barbarosa is only known from a single specimen collected before 1858 , one can not exclude that an additional, similar species occurs (or occured) in Madeira.

\footnotetext{
Opogona sacchati (BOJER, 1856)

[= subcervinella WALKER, 1863; = ligniferella WALKER, 1875; = sanctaehelenae WALKER, 1875; = plumipes BUTLER, 1876]
}

General distribution:

Probably originating from St. Helena and from there transported around the globe with maritime trade (ROBINSON \& TUCK, 1997: 386). O. sacchari is primarily a species of oceanic islands (the type localities of all five names listed above are Mauritius, St. Helena and Rodriguez). Other island records include Cape Verde Islands, Canary Islands, Azores and Bermuda. It is also known from costal areas of Africa, South and Central America, Florida, and from several places in Europe (DAVIS \& PENA, 1990). Whereas it may survive outdors in certain places in southern Europe, its occurence in northern Europe is exclusively connected with greenhouses and other heathed, humid localities.

Literature records from Madeira:

Opogona subcervinella (WALKER); WALSINGHAM, 1910: 259; REBEL, 1917: 13; BRADLEY, 1958: 196; GARDNER \& CLASSEY, 1959: 204.

Hieroxestis subcervinella (WALKER); COCKERELL, 1923: 247; RILEY, 1923: 286; REBEL, 1938: (65); REBEL, 1940a: 24; REBEL, 1940b: 8; REBEL, 1940c: 56-57.

Opogona sacchari (BOJER); KIIMESCH, 1980: 103; DAVIS \& PENÃ, 1990: 613; FERGUSON et al., 1991: 19; BÁEZ, 1993: 27; PASSOS DE CARVALHO, 1995: 561, 576; VIEIRA, 1997: 10; VIEIRA, 1998: 102. 
Adult (fig. 21). Wingspan 17-29 mm, and thereby the largest species of Tineidae in Madeira. Males of sacchari share with $O$. omoscopa a dorsal hair-pencil on the hindwing not found in other Madeiran Tineidae (on separation from omoscopa see under that species).

$0^{\star}$-genitalia (fig. 97-99).

o-genitalia (fig. 103-104).

Bionomy: The larva feeds on a number of different plants and trees, and it can be a serious pest on several crops, including banana, maize, potato, sweet potato and sugar cane. It can feed on nearly all parts of the banana. (DAVIS \& PENÃ, 1990).

In Madeira sacchari is spread all over the banana plantations. Other hosts in Madeira include bird of paradize (Strelitzia reginae) and sugar cane (Saccharum officinarum) (A. AGUIAR., in litt.). The adult is found throughout the year and comes to light.

Material examined:

10, Funchal, Monte, 13.IV.1904, leg. EATON (BMNH);

1 으, Funchal Lido, 20.-25.I.1970, leg. N. L. WOLFF (ZMUC);

1 ㅇ, Funchal Lido, 20.-31.V.1970, leg. N. L. WOLFF (ZMUC);

$30^{\circ}, 2$ 우, Funchal Lido, 20.-30.IV.1972, leg. N. L. WOLFF (ZMUC);

30, 6 \% , Funchal Lido, ult. XI.1972, leg. LUNDQVIST \& WOLFF (ZMUC);

10 , 9 9 , Funchal Lido, 4.-14.IX.1973, leg. LOMHOLDT \& WOLFF (ZMUC);

1\%, Serra d’Água, 660 m, 7.IX.1973, leg. LOMHOLDT \& WOLFF (ZMUC);

1\%, Funchal Lido, 17.-22.IV.1974, leg. N. L. WOLFF (ZMUC);

8 \%, Funchal Lido, 13.-26.VIII.1974, leg. E. TrAUgOTT-OlsEN (ZMUC);

1 i , Funchal Lido, 2.-5.V.1977, leg. N. L. WOLFF (ZMUC);

1 ㅇ, Serra d'Água, $650 \mathrm{~m}$, 5.V.1977, leg. N. L. WOLFF (ZMUC);

1 \%, Funchal, 50 m, 20.II.1979, leg. O. KARSHOLT (ZMUC);

3 9, Ponta do Sol, sea lev., 12.VI.1993, leg. O. Karsholt (ZMUC);

1 \%, Machico, sea lev., 10.VII.1993, leg. O. KARSHOLT (ZMUC);

$10^{\star}, 1 \%$, Ponta do Sol, sea lev. 16.IX.1994, leg. O. KArSHOLT (ZMUC);

$20^{*}$, Porto Santo, 14.IV.1996, leg. O. Karsholt (ZMUC);

20, Funchal Lido, $50 \mathrm{~m}, 19 .-20$. IX.1997, leg. O. KARSHOLT (ZMUC);

1ㅇ, Funchal, 21.X.1997, leg. H. HENDRIKSEN (ZMUC).

PASSOS DE CARVALHO (1995: 561) also recorded sacchari from Curral das Freiras and Caniçal.

O. sacchar is nowadays common in Madeira, especially along the southern coast, and in warm valleys it is found up to about $700 \mathrm{~m}$ altitude. It is therefore surprising that so few specimens of older date are available, and it is very probably that is was introduced to the island around the beginning of the last century. 


\section{Opogona omoscopa (MEYRICK, 1893)}

[F strassenella ENDERIEIN, 1903; = cpicalis SWEZEY, 1909; = pramatura MEYRICK, 1909]

General distribution:

Probably originating from St. Helena and from there transported around the globe with maritime trade (ROBINSON \& TUCK, 1997: 386). Known from Australia, New Zealand, Hawaii, India, southern Africa, Malagassy Republic; western North America (DAVIS, 1978: 23). Also in the Canary Islands, Azores and southern Spain. Occasionally introduced to greenhouses in northern Europe.

Literature records from Madeira:

Hieroxestis praematura MEYRICK; COCKERELL, 1923: 247; RILEY, 1923: 286; REBEL, 1938: (47); REBEL, 1940b: 8; REBEL, 1940c: 10, 45, 56.

Opogona omoscopa (MEYRICK); BRADLEY, 1958: 197; GARDNER \& ClASSEY, 1959: 204; PASSOS DE CARVALHO, 1995: 561, 576; BuHL et al., 1997: 152; VIEIRA, 1997: 10; VIEIRA, 1998: 102.

Adult (fig. 22). Similar to O. sacchari, but smaller (wingspan 15-22 mm), having darker forewings, with a yellowish tinge and a characteristic yellowish tornal spot.

$0^{*}$-genitalia (fig. 100-102).

o -genitalia (fig, 105-106).

Bionomy: The larva feeds on decaying and rotten tissues of a large number of different plants or trees (for details see DAvTs, 1978).

The early stages of omoscopa have, to our knowledge, not been studied in Madeira. The adult is found nearly throughout the year and comes to light.

Material examined:

$10^{\star}$, Funchal, Monte, 13.IV.1904, leg. EATON (BMNH);

50 , 9 \%, 20.-30.IV.1972, leg. N. L. WOLFF (ZMUC);

1 , Funchal, 17.VI.1972, leg. H. ENGHOFF (ZMUC);

40 , 9 9, Funchal Lido, ult. XI.1972, leg. LUNDQVIST \& WOLFF (ZMUC);

$20,2 q$, Funchal Lido, 4.-14.IX.1973, leg. LOMHOLDT \& WOLFF (ZMUC);

7\%, Funchal Lido, 17.-22.IV.1974, leg. N. L. WOLFF (ZMUC);

50,11 ㅇ, Funchal Lido, 13.-25.VIII.1974, leg. E. TRAUGOTT-OLSEN (ZMUC);

2 , Serra d'Água, Pousada dos Vinhaticos, 660 m, 15.VIII.1974, leg. E. TRAUGOTT-

OLSEN (ZMUC);

1 9, Funchal Lido, 18.-22.VIII.1974, leg. N. L. WOLFF (ZMUC);

1 ㅇ, Fajã da Nogueira, 600 m, 23.VIII.1974, leg. E. TRAUGOTT'-OLSEN (ZMUC);

100,19 , Fajã da Nogueira, 600 m, 28.VIII.1975, leg. N. L. WOLFF (ZMUC);

1오, Serra d'Água, Pousada dos Vinhaticos, 660 m, 31.VIII.1975, leg. N. L. WOLFF (ZMUC);

3ㅇ, Fajã da Nogueira, $600 \mathrm{~m}$, 14.-15.IX.1977, leg. LOMHOLDT \& WOLFF (ZMUC);

1 \%, Funchal, $50 \mathrm{~m}$, 18.II.1979, leg. O. KARSHOLT (ZMUC);

$29,3 \mathrm{~km}$ NE Chamacha de Lobos, $600 \mathrm{~m}, 13$. V.1989, leg. M. Hellers (MEY);

3 ㅇ, Poiso, $1400 \mathrm{~m}$, 13.V.1989, leg. M. HeLLERS (MMY);

10 , 1 \&, Fajã da Nogueira, 600 m, 15.V.1989, leg. M. HELLERS (MMY);

1 ㅇ, Paul da Serra, 1000 m, 18.V.1989, leg. M. HelLERs (MMY); 
19, 4 km NW Machico, 400 m, 20.V.1989, leg. M. HELLERS (MMY);

2\%, Fajã da Nogueira, 700 m, 5.VII.1981, leg. M. MEYER (MMY);

$10^{\star}$, N Cabo Girao, Quinta Grande, $700 \mathrm{~m}$, 7.VII.1991, leg. M. MEYER (MMY);

2\%, SW Porto do Moniz, Santa Madalena, Pico Alto, 600 m, 9.VII.1991, leg. M. MEYER (MEY);

$30^{\star}, 1$, , Ponta do Sol, sea lev., 12.VI.-4.VII.1993, leg. O. KARSHOLT (ZMUC);

1 \%, Faial, sea lev., 21.VI.1993, leg. O. KARSHOLT (ZMUC);

$10^{\star}, 2$ ㅇ, Machico, sea lev., 23.VI.-12.VII.1993, leg. O. KARSHOLT (ZMUC);

$10^{\star}$, Porto Moniz, sea lev., 4.VII.1993, leg. O. KarSHOLT (ZMUC);

2\%, Santana, $500 \mathrm{~m}$, 6.-8.X.1994, leg. O. KARSHOLT (ZMUC);

19, Santana, $530 \mathrm{~m}, 1$ 17.-20.IV.1996, leg. O. KARSHOLT (ZMUC);

1\%, Funchal Lido, 2.-5.V.1977, leg. N. L. WOLFF (ZMUC);

2\%, Funchal, 21.X.1997, leg. H. HENDRIKSEN (ZMUC);

$10^{7}$, Funchal, 20.-26.X.1997, leg. D. NILSSON (ZMUC).

PASSOS DE CARVALHO (1995: 561) also recorded omoscopa from Estreito de Camara de Lobos, Curral das Freiras, Santa, Chão da Ribeira, Queimadas, Caniçal and Porto Santo.

O. omoscopa is nowadays one of the commonest Lepidoptera in Madeira, especially along the coasts, but occasionally it is found up to about $1000 \mathrm{~m}$ altitude. It is terefore surprising that so few specimens of older date are available, and it is very probably that it was introduced to the island around the beginning of the last century.

Oinophila v-flava (HAWORTH, 1828)

[= flavofasciella DuPONCHEL, 1844; = vauflava HEYDENREICH, 1851; = v-flavella HERRICH-SCHÄFFER, $1855 ;=$ vauflavella BRUAND, 1859]

General distribution:

Widespread especially in warm temperate and subtropical areas, including central and southwestern Europe, the Canary Islands and Azores, South Africa, California and Juan Fernadez Islands (DAVIS, 1978). In the British Islands (as probably in most parts of central and northern Europe) it is mostly confined to cellars and warehouses, and only in the Isles of Scilly it seems to maintain outdoor populations (PELHAM-CLINTON, 1985).

Literature records from Madeira:

Oenophila vflavum (HAWORTH); WALSINGHAM, 1894a: 537, 542; REBEL, 1940b: 8; REBEL, 1940c: 10, 47.

Oenopbila v-flava (HAWORTH); WALSINGHAM, 1908: 1914.

Oinopbila v-flawn (HAWORTH); REBEL, 1896: 125; REBEL, 1901: 240; REBEL, 1911: 367; REBEL, 1917: 13.

Oinophila v-flava (HAWORTH); DAvIs, 1978: 31; KLIMESCH, 1980: 102; PELHAM-ClinTON, 1985: 241; PASSOS DE CARVALHO, 1995: 561, 576; VIEIRA, 1997: 10; VIEIRA, 1998: 102.

Adult (fig. 23). This species differs from other Madeiran Tineidae by its small size, and its brown forewings, with a distinct, angulated, yellow fascia in the middle, and by costal and tornal spots in the same colour. S. cyaneimarmorella has also slender, dark coloured wings, but these are without distinct markings.

$0^{*}$-genitalia (fig. 107-108).

o-genitalia (fig. 109-110). 
Bionomy: The larva feeds in the open on a variety of dry vegetable matters such as palm-tree bark and old grass cuttings. Indoors it frequents wine-cellars and has been found on fungus and on wine corks (DAVIS, 1987; PELHAM-CLINTON, 1985).

In spite of the many winecellars in Madeira the early stages have not been reported from there. Most specimens have been caught during the summer half-year.

Material examined:

2으, Funchal Lido, 20.-30.IV.1972, leg. N. L. WOLFF (ZMUC);

$10^{\circ}, 1$ \% , Funchal, 9.-13.VI.1972, leg. H. ENGHOFF (ZMUC);

1ㅇ, Funchal Lido, 17.-22.IV.1974, leg. N. L. WOLFF (ZMUC);

1 ㅇ, Funchal Lido, 13.-14.VIII.1974, leg. N. L. WOLFF (ZMUC);

1 \%, Funchal Lido, 6.-9.VI.1976, leg. N. L. WOLFF (ZMUC);

1\%, Madalena do Mar, Canhas, 100-300 m, 17.V.1989, leg. M. Hellers (MEY);

10 , Fajã da Nogueira, 500-700 m, 20.VI.1993, leg. O. KARSHOLT (ZMUC);

20,2 f , Ponta do Sol, sea lev., 29.VI.1993, leg. O. KARSHOLT (ZMUC);

1 ․ Porto Moniz, sea lev., 4.VII.1993, leg. O. KARSHOLT (ZMUC);

10 , Porto Santo, 14.III.1994, leg. P. de BjøRn \& J. DamgaARD (ZMUC);

1 , Curral das Freiras, 850 m, 27.IX.1997, leg. O. KARshOLT (ZMUC).

PASSOS DE CARVALHO (1995: 561) also recorded v-flava from Caniçal.

Widespread in the lowland and in warmer parts of the highland, but normally found only in singletons. This is in accordance with the suggestion of DAVIS (1978: 32) that: 'The moths are not strongly phototropic and consequently are not readily captured by normal methods'.

\section{Psychoides filicivora (MEYRICK, 1937)}

Literature records from Madeira:

Psychoides filicivora (MEYRICK); KARSHOLT, 1996: 302.

Psychoides verbuella (misidentification); PASSOS DE CARVALHO, 1995: 575

General distribution:

Outside of Madeira only known from the British Isles.

Adult (fig. 24). P. filicivora slightly resembles a species of Tinea. It can be recognized by its dark fuscous forewings, having a violet gloss, a yellowish white tornal spot and a few yellowish spots along termen; the frons of the head is ochreous, and the male antennae are serrate-ciliate, with ciliae of more than twice the diameter of the shaft.

o-genitalia (fig. 111-113).

o-genitalia (fig. 114-115).

Bionomy: The larva feeds on a varity of ferns, eating sporangia on the lower front surface, usually under a cover of sporangia spun into an irregular mass (PELHAM-CLINTON, 1985). In Madeira numerous small larvae were found feeding on sporangia of Asplenium sp. at Serra d'Água, $640 \mathrm{~m}, 11 . v i .1993$, leg. O. KARSHOLT. The adult is active during day and is apparently not attracted to light. From the few observations it is not clear if filicivora has one or more generations per year in Madeira. 
Material examined:

$10^{\star}$, Queimadas, 1.V.1980, leg. M. SERRANO (JPC);

$17 \%, 3$, Encumeada, $1000 \mathrm{~m}, 14 .-18 . \mathrm{VI} .1993$, leg. O. KARSHOLT (ZMUC);

$20^{*}, 2$ ㅇ Achaidas da Cruz, 700 m, 19.IV.1996, leg. O. KARSHOLT (ZMUC);

$20^{*}$, Portela, $620 \mathrm{~m}$, leg. A. DIAKONOFF (RMNH).

Remarks: Since its description filicivora has been regarded an endemic species of the British Islands, even though it was considered likely that it originated from elsewhere (because a related species occurs in Japan) (PELHAM-CLINTON, 1985). In Madeira filicivo$r a$ mainly occurs in undisturbed laurisilva localities, and that normally indicates that it belongs to the original fauna of the island, from the time before the impact of man. We therefore believe that filicivora is originally a Madeiran endemic which has been introduced to The British Islands with ferns for gardening. A few species of Blastobasis, also originally endemic for Madeira, have in a similar way established themselves in the British Islands (KARSHOLT \& SINEV, in prep.).

\section{Acrolepiidae}

Members of Acrolepiidae can be separated from other Microlepidoptera in Madeira by having upcurved labial palps, naked haustellum and neck with errected hairs. Most of the few hitherto known specimens have been caught at light in laurisilva localities in the humid, northern part of Madeira.

\section{Acrolepiopsis vesperella (ZELLER, 1850)}

[= smilaxella MILLIÈRE, 1864; = tami HERING, 1927]

General distribution:

Recorded from nearly all countries around the Mediterranean Sea, also from the Canary Islands.

Adult (fig. 25). Forewing brown, darkest at base, lighter towards apex. In some specimens the dorsum is whitish. For differences to $A$. mouli and infundibulosa see under those species.

ot-genitalia (fig. 116-117).

o-genitalia (fig. 120-121).

Bionomy: Larvae are miners on Smilax canariensis and Tamus edulis.

The few specimens have been collected at light in laurisilva localities, and this may indicate that vesperella is an old element in the Madeiran fauna.

Material examined:

10 , Achadas da Cruz, 725 m, 8.VII.1993, leg. O. KARSHOLT (ZMUC);

$10^{*}$, Fajã de Noguiera, 600-1000 m, 8.X.1994, leg. O. KARSHOLT (ZMUC);

1 ㅇ, Ribeira da Janela, $600 \mathrm{~m}, 14 . X .1994$, leg. O. KARSHOLT (ZMUC).

First records from Madeira. 


\section{Acrolepiopsis mauli sp. $\mathrm{n}$.}

Material examined: 10,3 ㅇ:

Holotype, or, Madeira, $700 \mathrm{~m}$, Achadas da Cruz, 10.X.1994, leg. O. KARSHOLT, genital slide No. 4849 O. KARShOLT (ZMUC); Paratypes: 1 \%, Madeira, Serra d’Água, Pousada des Vinhaticos, 600 m, 15.-16.VIII.1974, leg. NiEls L. WOLFF (ZMUC); 1 \% , Madeira, 1000 m, Encumeada, 13.VI.1993, leg. O. KARSHOLT (ZMUC); 1 ㅇ, Madeira, 1300 m, Ribeira de Janela, 14.X. 1994, leg. O. KARSHOLT (DEI).

Adult. 0 : Wingspan $10 \mathrm{~mm}$; vertex light grey, nearly white, on sides darker grey; palpi long, curved upwards, pointed, the inner side white, the outside dark brown; thorax and tegulae grey-brown; the ground color of forewing dark grey-brown, dorsally before $1 / 2$ a white triangular spot, overlaid with dark scales, a minute white dot at base of cilia; costa with some whitish, short streakes, at $1 / 2$ and $3 / 4$ expanded to one whitish patch, partly overlaid with dark scales, whole forewing with additional very small white dots; before the apex a clearly separated dark dot; of (fig. 26): wingspan $14 \mathrm{~mm}$; vertex dark brown-grey, lighter only below palpi; the ground color of forewings darker, the triangular spot at dorsum only somewhat lighter than surrounding area, streakes at costa clearly white only in last half, otherwise dark ochre.

o'-genitalia (fig. 118-119): Saccus long, narrower before the broad rounded apex; valva typical for the genus, with broad basic part, costal arm nearly parallel-sided, at upper edge with a half-moon-shaped sclerotization; aedeagus nearly 1.5 times longer as whole genitalia, with enlarged basis, light bended, apex sclerotized only on the one side.

O-genitalia (fig. 122): Clublike structures broadly oval, bearing setae, tapering to a point; ostium with pointed sclerotized processus; posterior part of ductus bursae scletotized. Signum with two small, semi-ovale, slightly dentate signa. Posterior margin of sternite VII without emargination.

Bionomy: Early stages unknown. Most of the few adults were collected at light in laurisilva localities in the highland.

Remarks: Rather similar to $A$. infundibulosa (see under that species). Differs from vesperel$l a$ in having broader wings, and the colour of the forewings more marbled brown and whitish yellow. The structures of the genitalia (valva, ostium and ductus bursae) are typical and the new species should not be confused with any other known species of this genus.

The new species is named in honour to the late Dr. G. E. MAUL of Municipal Museum in Funchal for his helpfulness to scientists working on the natural history of Madeira.

\section{Acrolepiopsis infundibulosa sp. $\mathrm{n}$.}

Material examined: 3 ㅇ

Holotype, + , Madeira, $700 \mathrm{~m}$, Achadas de Cruz, 10.X.1994, leg. O. KARsHolt, genital slide R. GAEDIKE No. 4729 (ZMUC); Paratypes: 1 9 , same locality and date (ZMUC); 19, Madeira, 1000 m, Encumeada, 3.VII.1993, leg. O. KAR.SHOLT (DED). 
Adult (fig. 27). Wingspan 13-15 mm; vertex, thorax and the upwards-curved, pointed palpi dark brown, inner side of palpi lighter; ground colour of the forewings dark brown; at dorsum at $1 / 2$ a large white triangular dot, sometimes overlaid with dark scales, an additional very small white dot at beginning of ciliae, on costa at $3 / 4$ a light brown triangular area, strictly fenced to basis, reaching nearly to dorsum, a small, also light brown coloured dot before apex.

đo-genitalia: Hitherto unknown.

\%-genitalia (fig. 123): Clublike structure broad, set with setae, pointet apically; ostium enlarged, funnel-shaped, set with micro-thorns; together with posterior part of ductus bursae strongly sclerotized. Corpus bursae with numerous micro-spines, no signa present. Posterior margin of sternite VII with broad emargination.

Bionomy: Early stages unknown. The few adults were collected at light in localities with luxuriant laurisilva, partly together with Acrolepiopsis manli.

Remarks: The clearly visible, light brown triangular area on costa at $3 / 4$ of the dark brown forewings, reaching nearly to dorsum separates infundibulosa from mouli and vesperella. The large, funnel-shaped ostium is an additional characteristic for recognization. The two species described here as new are related to assectella in the shape of the ductus bursae having a distinct sclerotization.

The name of this new species refers to the form of the ostium (infudibulum = latin name for funnel).

\section{Epermeniidae}

The single representative in Madeira belonging to this family can be recognized by its slender wings with three or four raised scale-patches at dorsum.

Epermenia aequidentella (HOFMANN, 1867)

[ $=$ daucellus PEYERIMHOFF, 1870]

Literature records from Madeira:

Chauliodus daucellus (PEYERTMHOFF); WALsInghaM, 1894a: 538, 554.

Epermenia daucella (PEYERIMHOFF); REBEL, 1901: 179; WALSINGHAM, 1908: 974; HERING, 1927: 435; REBEL, 1940a: 22; REBEL, 1940b: 8.

Epermenia aequidentella (HOFMANN); KIIMESCH, 1983: 101; PASSOS DE CARVALHO, 1995 : 570, 580; VIEIRA, 1997: 230; VIEIRA, 1998: 102; 1998: 104.

General distribution:

Recorded from nearly all of Europe (apart from Scandinavia) from Spain northwards to Great Britain, eastwards to the Caucasus area, southwards to Greece; also recorded from the Canary Islands and Azores, Lebanon, Turkey, Iran and from Mongolia.

Adult (fig. 28). See about under 'Epermeniidae'.

o-genitalia (fig. 124-125).

o-genitalia (fig. 126-127). 
Bionomy: Larvae on several umbelliferous plants, e. g. Angelica sp., Daucus carota, Peucedanum sp., Meum athamanticum, Anthriscus vulgaris, Thapsia villosa, Libanotis montana and Pimpinella saxifraga. In the first stages they are miners, later they feed on leaves and into seeds. In Madeira widely distributed from sea level to above $1000 \mathrm{~m}$, prefering open, herb-rich localities. The adult can be disturbed during day and comes to light, but it is rarely numerous.

Material examined:

10, Fuchal - Lido, 4.-14.IX.1973, leg. N. L. WOLFF (ZMUC);

$1 \%$, Serra d’Água, Pousada dos Vinhaticos, $600 \mathrm{~m}, 19 . \mathrm{VIII} .1974$, leg. E. TRAUGOTTOLSEN (ZMUC);

1 \%, Serra d’Água, Pousada dos Vinhaticos, $600 \mathrm{~m}, 23$. VIII.1974, leg. N. L. WolfF (ZMUC);

1 o , 1 ㅇ, Caniço, 12.-18.IX.1977, leg. LOMHOLDT \& WOLFF (ZMUC);

1 ex, Pico-Cabeco do Monte, 6.VII.1981 (JPC);

1 ex, Curral das Freiras, 16.VII.1981 (JPC);

1 đ., N. Pto. Encumeada, Lamaceiros, 900 m, 11.VII.1991, leg. M. MEYER (MMY);

1 \%, São Vicente, sea lev., 12.VI.1993, leg. O. KARsholT (ZMUC);

1ð, Faial, sea lev., 21.VT.1993, leg. O. KARshOLT (ZMUC);

10, Machico, sea lev., 25.VI.1993, leg. O. KARSHOLT (ZMUC);

10 , Ponto de São Lourenco, sea lev., 26.VI.1993, leg. O. KARSHOLT (ZMUC);

40, 1 ㅇ Machico, sea lev., 27.VT.1993, leg. O. KARSHOLT (ZMUC);

$10^{\star}$, above Madalena del Mar, 780 m, 29.VI.1993, leg. O. KARSHOLT (ZMUC);

$20^{*}$, Serra d'Água, 580 m, 1.-2.VII.1993, leg. O. KARSHOLT (ZMUC);

$10^{*}$, Encumeada, $1000 \mathrm{~m}$, 3.VII.1993, leg. O. KARSHOLT (ZMUC);

$10^{*}$, Porto Moniz, sea lev., 4.VII.1993, leg. O. Karsholt (ZMUC).

Records in the literature:

REBEL (1940a: 22) also recorded this species (as Epermenia daucella PEYERIMHOFF) from Rabaçal (1089 m).

\section{Acknowledgements}

We are indebted to the following for information or loan of material; Dr. ANTONIO M. F. AGUiAR, Camacha, Madeira; Mr. E. ARENBERGER, Wien, Austria; Dr. DonALD R. DAVIS, NMNH, Washington, USA; Dr. António Domingos ABreu, MMF, Funchal, Madeira; Mr. HAns HenderJckX, Mol, Belgium; Prof. Niets P. KRISTENSEN, ZMUC, Copenhagen, Denmark; Dr. MARC MEYer, Perl-Kesselingen, Germany; Dr. José Passos de Carvalho, Oeiras, Portugal; Dr. Gaden Robinson and Mr. Kevin Tuck, both BMNH, London, U. K. We moreover acknowledge the photographic work made by Mr. GEERT BROVAD, ZMUC, and the linguistic correction by Dr. MARY E. PETERSEN, both ZMUC, Copenhagen, Denmark. The work by O. KARSHOLT on the Lepidoptera of Madeira project was supported by a grant from the CARLSBERG Foundation, Denmark

The studies by R. GAEDIKE on Tineidae in the Smithsonian Institution were supported by a SMITHSONIAN Institution Short-Term visitor award. 


\section{References}

AgUiAR, A.M.F. \& KARISHOLT, O. In press: Systematic catalogueof the entomofauna from the Madeira Archipelago and Seluages Islands - Bolm Mus. munic. Funchal, Supl. 7.

BAEZ, M. 1993: Origins and affinities of the Fauna of Madeira. - Bolm Mus. munic. Funchal, Supl. 2: 9-40. BÁEZ, M. 1998: Mariposas de Canarias. - vi + 216 pp. Madrid.

Bradley, J. D. 1958: Pytales and Microlepidoptera collected by Mr. E. W. Classey in Madeira, 1957. Entomologist London 91 (1144): 192-197.

Buhl, O.; FAlCK, P.; JørGensen, B.; Karsholt, O.; LARSEN, K. \& VIlHelmsen, F. 1997: Fund af småsommerfugle fra Danmark i 1996. Ent. Meddr 65: 149-158.

CLARKE, J. F. G. 1970: Catalogue of the Type specimens of Microlepidoptera in the British Museum (Natural History) described by EDWARD MEYRICK 8: 1-261, 60 plates. London.

COCKERELL, T. D. A. 1923: The Lepidoptera of the Madeira Islands. - Entomologist London 56: 243-274, 286.

DAVTS, D. R. 1978: The North American Moths of the genera Pbaeoses, Opogona and Oinopbila, with a Discussion of Their Supergeneric Affinities (Lepidoptera: Tineidae). - Smithson. Contr. Zool. 282: i-iii, 1-39.

DAVIS, D. R. \& PENÃ, J. E. 1990: Biology and morphology of the banana moth, Opogona sachari (BOJER), and its introduction into Florida (Lepidoptera: Tineidac). - Proc. entomol. Soc. Wash. 92: 593-618.

Ferguson, D. C.; HILBURN, D. J. \& WRIGHT, B. 1991: The Lepidoptera of Bermuda: Their food plants, biogeography, and means of dispersal. - Mem. ent. Soc. Can. 158: 1-105.

GARDNER, A. E. \& CLASSEY, E. W. 1960: Report on the insects collected by the E. W. CLASSEY and A. E. GARDNER Expedition to Madeira in December 1957. - Proc. S. Lond. ent. nat. Hist. Soc. 1959: 184-206.

HANNEMANN, H.-J. 1977: Kleinschmetterlinge oder Microlepidoptera III. Federmotten (Pterophoridae) Gespinstmotten (Yponomeutidae) Echte Motten (Tineidae). - Tierwelt Deutschlands 63: 1-275, pls 1-17.

HeRING, E. M. 1927: Die Minenfauna der Canarischen Inseln. - Zool. Jb., Abt. f. Syst. 53: 405-486.

HrNTON, H. E. 1956: 'The larvae of the species of Tineidae of economical importance. Bull. ent. Res. 47: 251-346.

HINTON, H. E. \& BRADLEY, J. D. 1956: Observations on species of Lepidoptera infesting stored products. XVI: Two new geneta of Clothes Moths (Tineidae). - Entomologist London 89 (1113): 42-47, 4 figs.

KARSHOLx, O. 1996: Note on Psychoides filicivora, p. 302. - In: O. KARSHOLT \& J. RAZOWSKI: The Lepidoptea of Europe. A Distributional Checklist. Stenstrup.

KARSHOLT, O. 2000: Contribution to the Lepidoptera fauna of Madeira 1. Introduction. - Beitr. Ent. Berlin 50 (2): 397-405, 4 figs.

Karsholt, O. \& Nielsen, E. S. 1986: The Lepidoptera described by C. P. ThunBERG. - Ent. scand. 16: 433-463.

KuMESCH, J. 1980: Beitraege zur Kenntnis der Microlepidopteren-Fauna des Kanarischen Archipels 3. Beitrag: Tineidae, Hieroxestidae. Vieraea 9 (1979): 91-114.

KLIMESCH, J. 1983: Beiträge zur Kenntnis der Microlepidopteren-fauna des Kanarischen Archipels 5. Beitrag: Choreutidae, Actolepiidae, Epermeniidae, Tinaegetiidae, Momphidae, Cosmopterigidae, Walshiidae. - Vieraea 12 (1982): 95-112.

KOÇAK, A. Ö. 1981: More notes on the homonymy of the specific names of Lepidoptera. - Priamus 1:110-111.

MEYRICK, E. 1916-1923: Exotic Microlepidoptera 2. - 640 pp. Marlborough.

Nordman, A. F. \& REBEL, H. 1935: Verzeichnis der von Richard FrEY und RAGNAR STORÅ auf den Kanarischen Inseln gesammelten Lepidopteren. Commentat. biol., 6: 1-20.

PAssos DE CARvalHo, J. 1995: Microlepidoptera of the Madeira and Selvagem Archipelagoes (Insecta, Lepidoptera). - Bolm Mus. munic. Funchal, Supl. 4: 559-588.

Pelham-Cinnton, E. C. 1985: Tineidac, Hieroxestidae. Pp. 152-212, 240-243, pls 8-10. - In: J. HeAtH \& E. M. EMMET (eds): The moths and butterflies of Great Britain and Ireland 2. Colchester.

Petersen, G. 1957-58: Die Genitalien der paläarktischen Tineiden. - Beitt. Ent. Berlin 7: 55-176, 338-379, $557-595 ; 8: 111-118,398-430$.

PETERSEN, G. \& GAEDIKE, R. 1979: Beitrag zur Kenntnis der Tineiden-Fauna des Mittelmeertaumes. Beitt. Ent. Berlin 29: 383-412.

REBEL, H. 1892: Beitrag zur Microlepidopterenfauna des canarischen Archipels. - Annln naturh. Mus. Wien 7: 241-284, pl. XVII.

REBEL, H. 1896: Dritter Beitrag zur Lepidopterenfauna det Canaren. Annln naturh. Mus. Wien 11: 102147, pl. III.

ReBel, H. 1901: II. Theil: Famil. Pyralidae-Micropterygidae. Pp. 1-368. - In: H. ReBEL \& O. STAUdinger: Catalog der Lepidopteren des Palaearctischen Faunengebietes. Berlin.

REBEL, H. 1906: Fünfter Beitrag zur Lepidopterenfauna der Kanaren. - Annln naturh. Mus. Wien 14: 22-44. 
ReBEL, H. 1911: Sechster Beitrag zur Lepidopterenfauna der Kanaren. - Annln naturh. Mus. Wien 24: 327374, pl. XII.

ReBEI, H. 1917: Siebenter Beitrag zur Lepidopterenfauna der Kanaren. - Annln naturh. Mus. Wien 31: 1-62.

REBEL, H. 1938: Achter Beitrag zur Lepidopterenfauna der Kanaren. - Annln naturh. Mus. Wien 49: (43)-(68).

ReBEL, H. 1940a: Die Arthropodenfauna ron Madeira nach den Ergebnissen der Reise von Prof. Dr. O. LUNDBLAD Juli - August 1935. XXI. Lepidoptera: Microlepidoptera. - Ark. Zool. 32A (2): 1-26, tab. IIII.

ReBEL, H. 1940b: Die Arthropodenfauna von Madeira nach den Ergebnissen der Reise von Prof. Dr. O. LUNDBLAD Juli - August 1935. XXIII. Übersicht der Lepidopterenfauna Madeiras. - Ark. Zoo. 32A (5): $1-13$.

REBEL, H. 1940c: Die Lepidopterenfauna des Azorischen Archipels. Mit 1. Anhang: Eine LepidopterenAusbeute von Madeira. - Commentat. biol. 8 (1): 1-59, pls I-II.

REBEL, H. \& RogenHofer, A. 1894: Zur Lepidopterenfauna der Canaren. - Annln naturh. Mus. Wien, 9: $1-96$, pl. I.

RILEY, N. D. 1923: The Lepidoptera of the Madeira Islands. Entomologist 56: 286.

RoBINSON, G. S. 1979: Clothes-moths of the Tinea peltionella complex: a revision of the world's species (Lepidoptera: Tineidae). - Bull. Brit. Mus. (N. H.) Ent. series 38 (3): 57-128.

ROBINSON, G. S. 1988: The identity of Trichophaga abruptella (WOLLASTON) (Lepidoptera: Tineidae). Entomologist’s Gaz. 39: 125-128.

Robinson, G. S. \& NiELSEN, E. S. 1989: Tineid genera of Australia. - Monogr. Austr. Lepid. 2. xv + 344 pp. Melbourne.

RoBINSON, G. S. \& TUCK, K. R. 1997: Phylogeny and composition of the Hieroxestinae (Lepidoptera: Tineidae). - Syst. Ent. 22: 363-396.

STATNTON, H. T. 1859: Notes on Lepidoptera collected in Madeira by T. V. WOLLASTON Esq. with descriptions of some new species. - Ann. Mag. nat. Hist. London 3 (3): 209-214.

VIERA, V. 1997: Lepidoptera of the Azores Islands. - Bolm Mus. munic. Funchal 49: 5-76.

VIERA, V. 1998: Biogeografia dos Lepidópteros (Insecta, Lepidoptera) dos Açores. - Revista Biol. Lisb. 16: $87-106$.

WALKER, F. 1864: List of the specimens of Lepidoptetous Insects in the collection of the British Museum. Part XXX. - Tineites: 837-1096. London.

WALSINGHAM, T. de Grey 1894a: Catalogue of the Pterophoridae, Tortricidae, and Tineidae of the Madeira Islands, with notes and descriptions of new species. - Trans. ent. Soc. London 1894: 535-555.

WALSINGHAM, T. de Grey 1894b: Microlepidoptera from Norfolk and Scotland: including an addition to the British list. - Entomologist's mon. Mag. 30: 50-52.

WALSINGHAM, T. de Grey 1908: Microlepidopters of Tenerife. - Proc. zool. Soc. Lond. 1907: 911-1034.

WALSINGHAM, T. de Grey 1910: Madeiran Tineidae (Lepidoptera). - Entomologist's mon. Mag. 46: 257259.

WALSINGHAN, T. de Grey \& HAMPSON, B. A. 1896: On moths collected at Aden and in Somaliland. - Proc. zool. Soc. Lond. 1896: 257-283.

WOLLASTON, V. T. 1858: Brief diagnostic characterization of undescribed Madeiran insects. - Ann. Mag. nat. Hist. 1 (3): 113-125.

\section{Author's addresses:}

Dr. REINHARD GAEDIKF

Deutsches Entomologisches Insititut (DEI)

im Zentrum für Agrarlandschafts- und

Landnutzungsforschung (ZALF)

Schicklerstraße 5

D-16225 Eberswalde

e-mail: gaedike@zalf.de
OLE KARSHOLT

Zoologist Museum

Universitetsparken 15

DK-2100 København $\varnothing$

e-mail: okarsholt@zmuc.ku.dk 

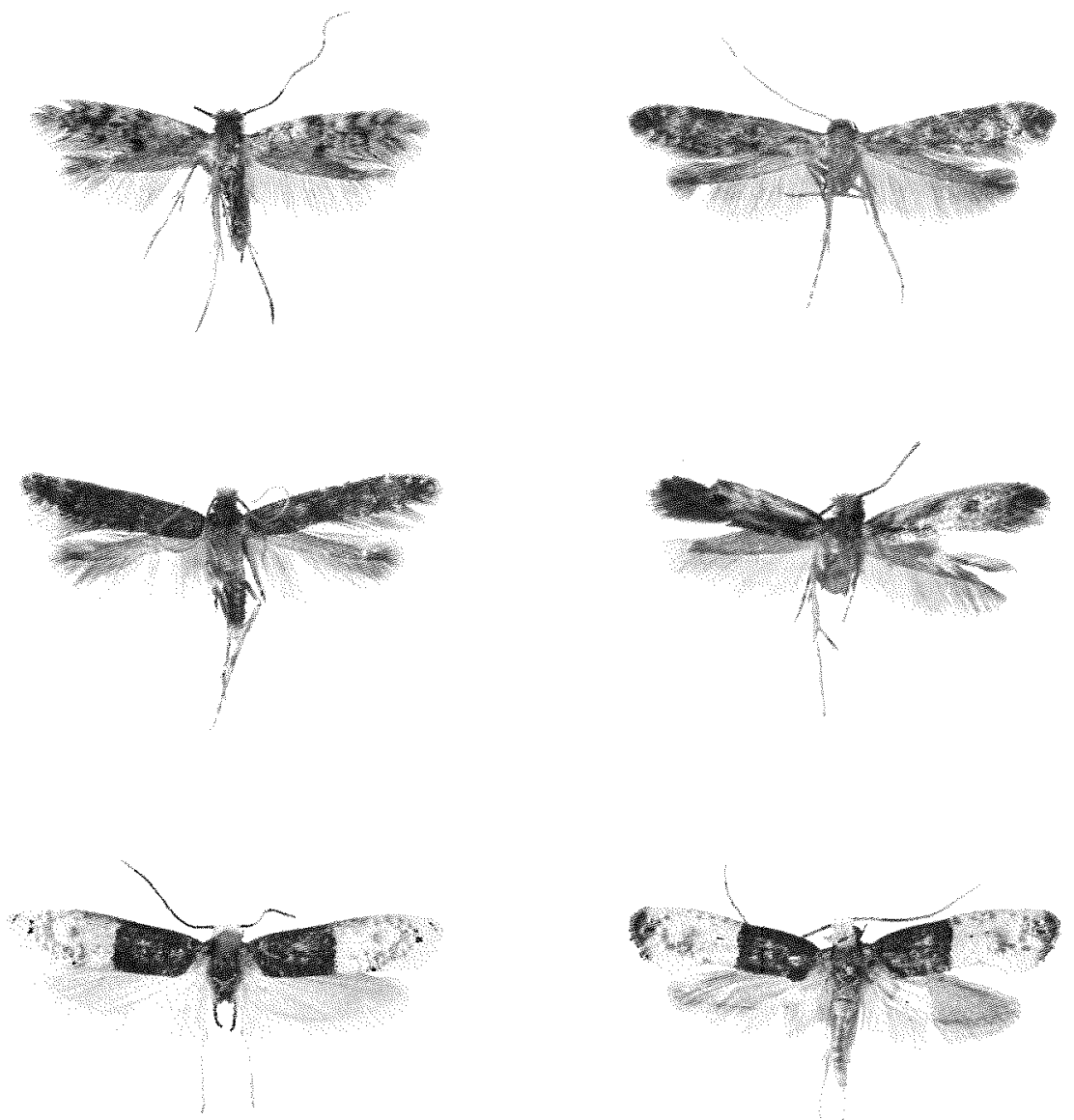

5

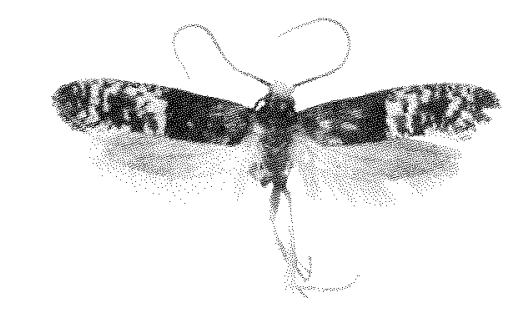

7

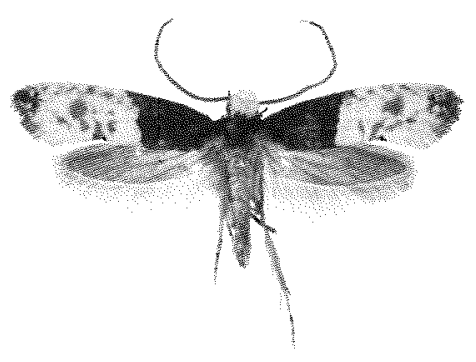

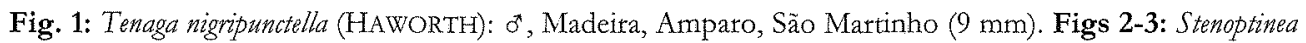
yaneimamorella (MILLIÈRE): 2 - o, Madeira, Curral das Freiras (12 mm), 3 - o, without locality $(13 \mathrm{~mm})$. Fig. 4: Ceratobia oxymora (MEYRICK): $\sigma^{\star}$, Madeira, Funchal $(8 \mathrm{~mm}$ ). Fig. 5: Trichophaga rabinsoni nom. n.: o , Madeira, Ponta de São Lourenco (23 mm). Figs 6-7: Trichophaga bipartitella (RAGONOT): 6 - 0 , Canary Isl., Gomera (18 mm), 7 - 0 , Selvages Isl., Selvagem Grande $(17 \mathrm{~mm})$. Fig. 8: Trichophaga tapetzella (LINNAEUS): $0^{*}$, Madeira, Funchal Lido (14 mm). 
9

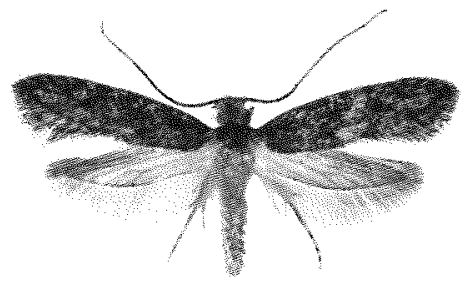

11
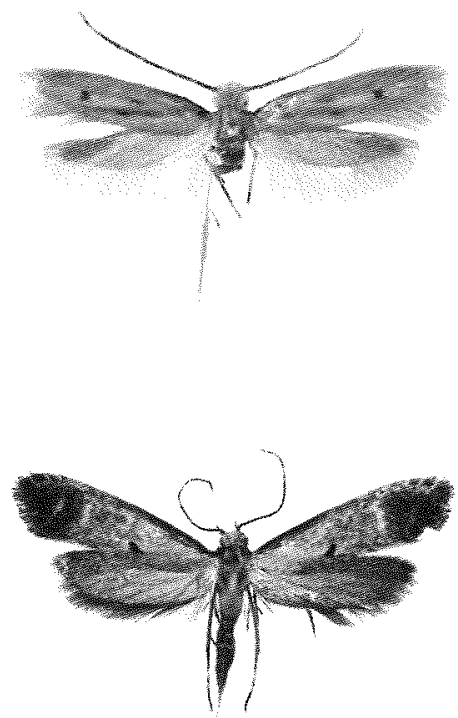

13

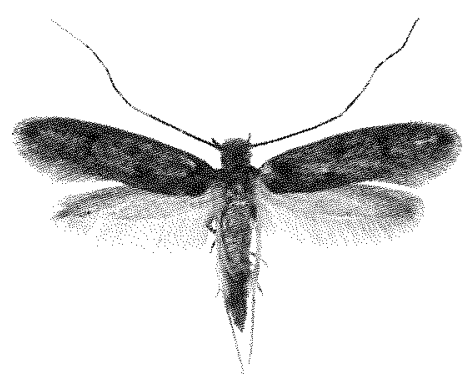

15

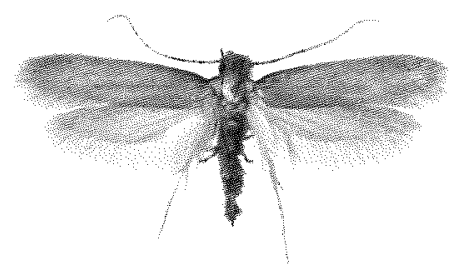

10

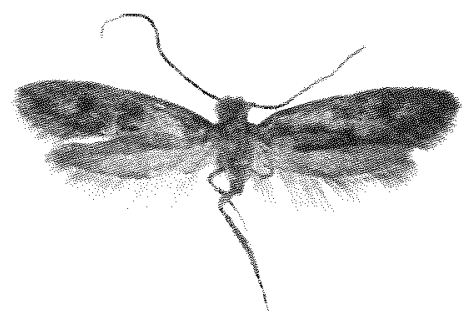

12

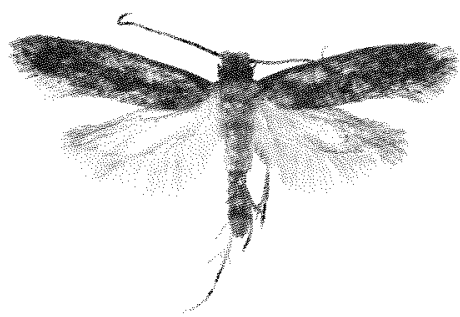

14

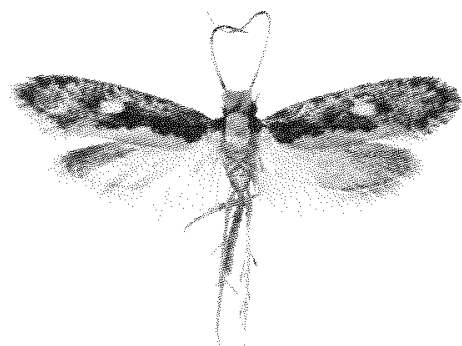

Fig. 9: Praeacedes atomosella (WALKER): $\sigma$, Porto Santo $(11 \mathrm{~mm})$. Fig. 10: Tineola bisselliella (HUMMEL): o, Denmark $(13 \mathrm{~mm})$. Fig. 11: Tinea murariella STAUDINGER: on, Madeira, Funchal $(10 \mathrm{~mm})$. Fig. 12: Tinea dubiella StAINTON: ơ, Madeira, Serra d’Ágra $(12 \mathrm{~mm})$. Fig. 13: Tinea trinotella Thunberg: 9 , Madeira, N. Pto Encumeada, Lamaceiros (18 mm). Fig. 14: Niditinea fuscella (LINNAEUs): $\sigma$, Madeira, Funchal Lido (10 mm). Fig. 15: Phaereoeca allutella (REBEL): o, Madeira, Santa Cruz (19 mm). Fig. 16: Monopis crocicapitella (CLEMENS): $0^{\star}$, Madeira, Machico $(11 \mathrm{~mm})$. 

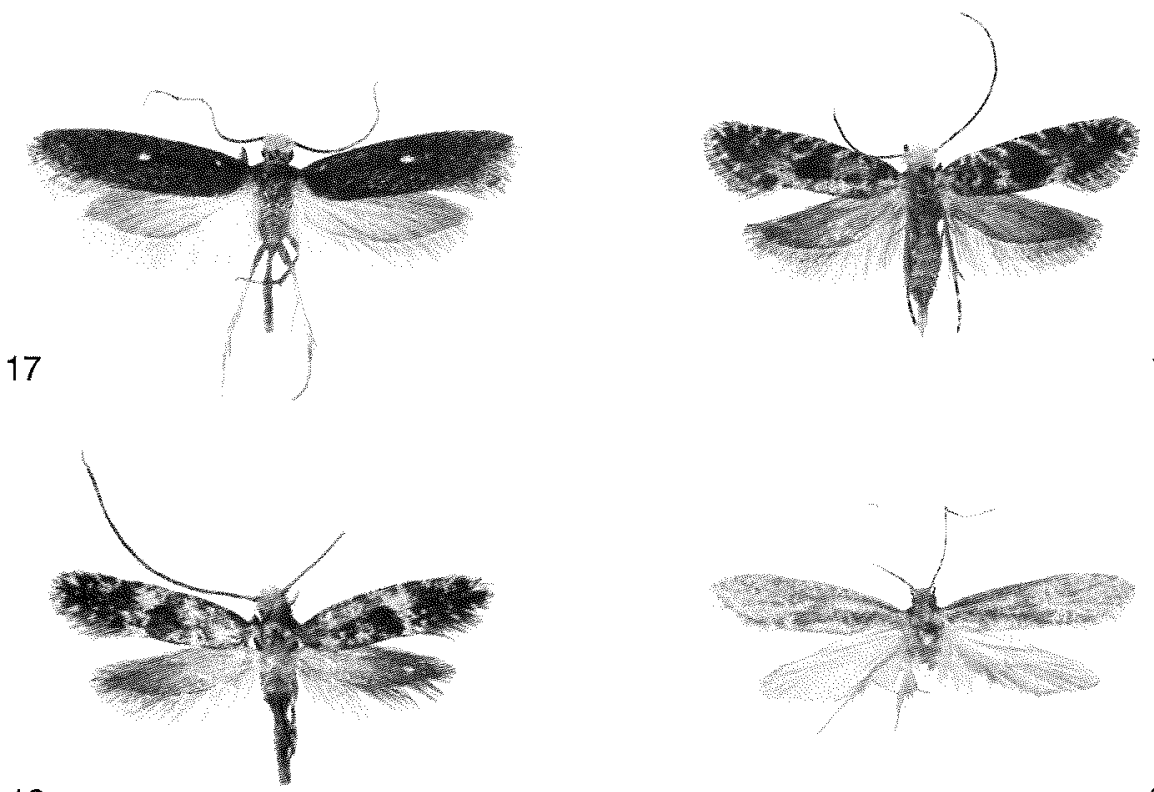

19
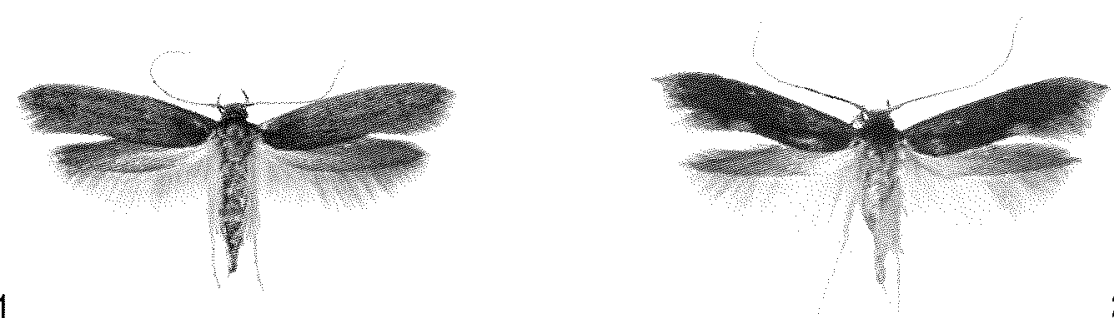

23
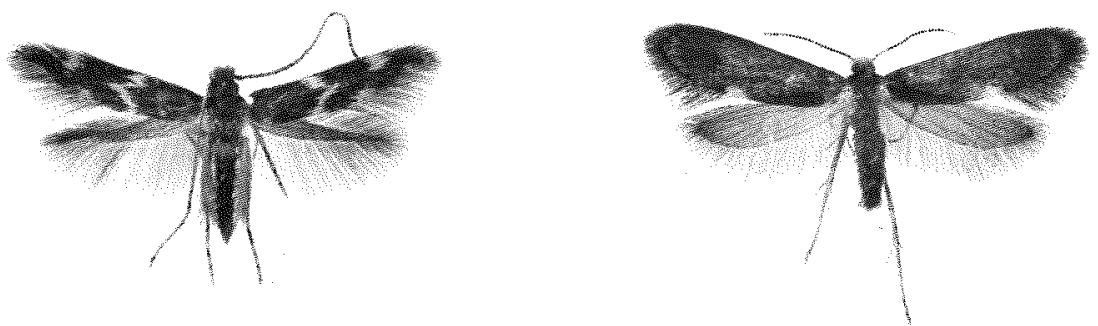

Fig. 17: Monopis nigricantella (MILIIÈRE): $0^{\star}$, Madeira, Funchal, $(16 \mathrm{~mm})$. Figs 18-19: Monopis benderickxi sp. n.: 18 - 9 , Paratype, Madeira, Serra do Rosario $(10 \mathrm{~mm}), 19-0$, Paratype, chada do Teixeira $(9 \mathrm{~mm})$. Fig. 20: Monopis barbarosi KOÇAK: , holotype, Madeira (without exact locality). Photo prepared from two colour slides. Fig. 21: Opogona saccbari (BOJER): \%, Madeia, Funchal Lido $(28 \mathrm{~mm})$. Fig. 22: Opogona omoscopa (MEYRICK): + , Madeira, Funchal Lido (19 mm). Fig. 23: Oinophila v-flava (HAWORTH): $\sigma^{\circ}$, Madeira, Fajã de Nogueira (9 mm). Fig. 24: Psychoides filicivora (MEXRICK): 9 , Madeira, Encumeada (10 mm). 

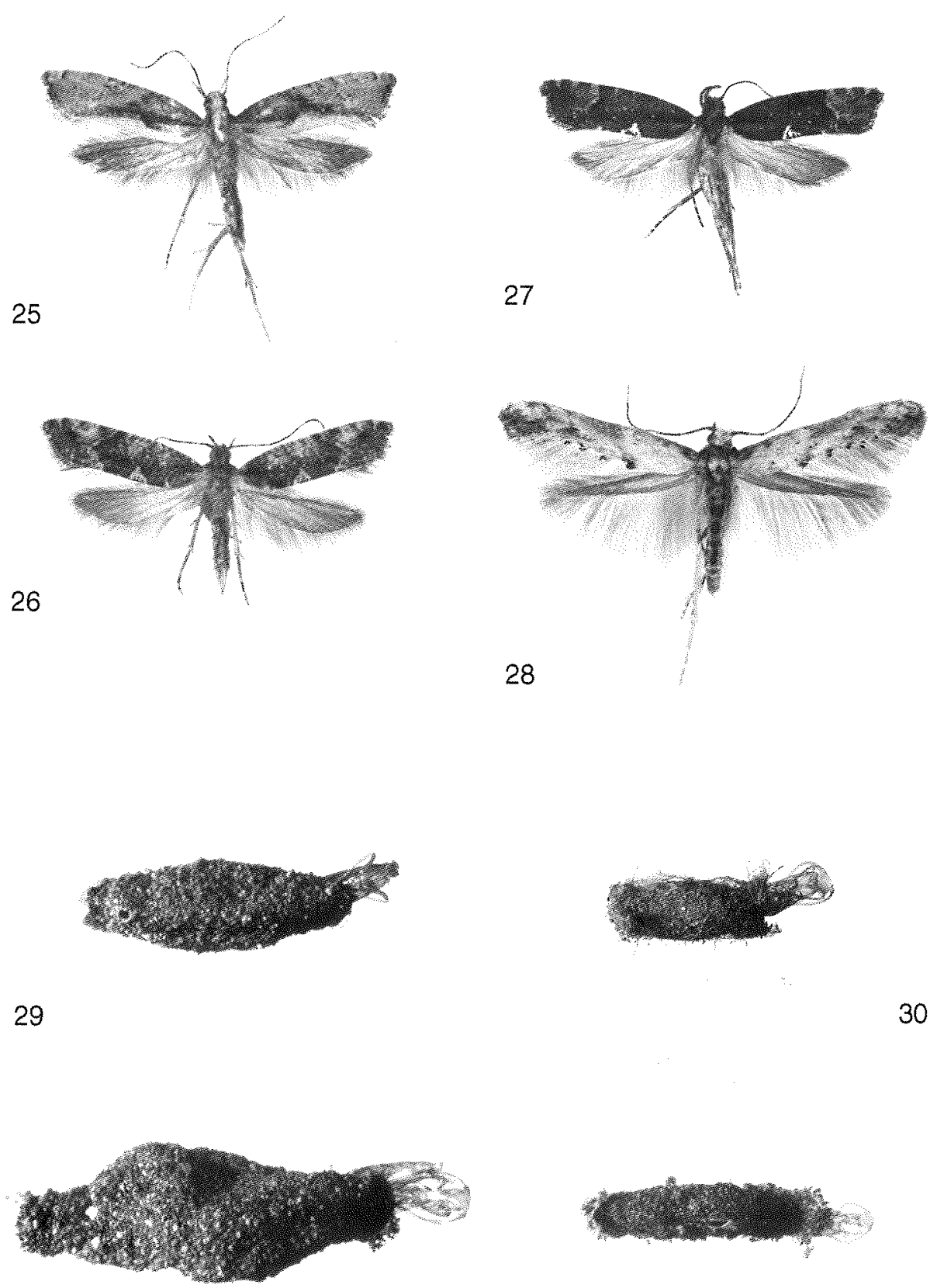

31

Fig. 25: Acrolepiopsis vesperella (ZELLER): \%, Madeira, Achadas da Cruz (12 mm). Fig. 26: Acrolepiopsis mauli sp. n.: + , paratype, Madeira, Encumeada (14 mm). Fig. 27: Acrolepiopsis infundibulosa sp. n.: o, paratype, Madeira, Achadas da Cruz (14 mm). Fig. 28: Epermenia aequidentella (HOFMANN): O', Madeira, Serra d’Água $(13 \mathrm{~mm})$. Figs 29-32: Larva cases of Madeitan Tineidae: 29 - Praeacedes atomosella (WALKER) $(9 \mathrm{~mm}), 30$ Tinea murariella StAUDINGER (5 mm), 31- Phaereoeca allutella (REBEL) $(13 \mathrm{~mm}), 32$ - Monopis benderickxi sp. $\mathrm{n}$. $(8 \mathrm{~mm})$. Measured lengts without exuviae. 

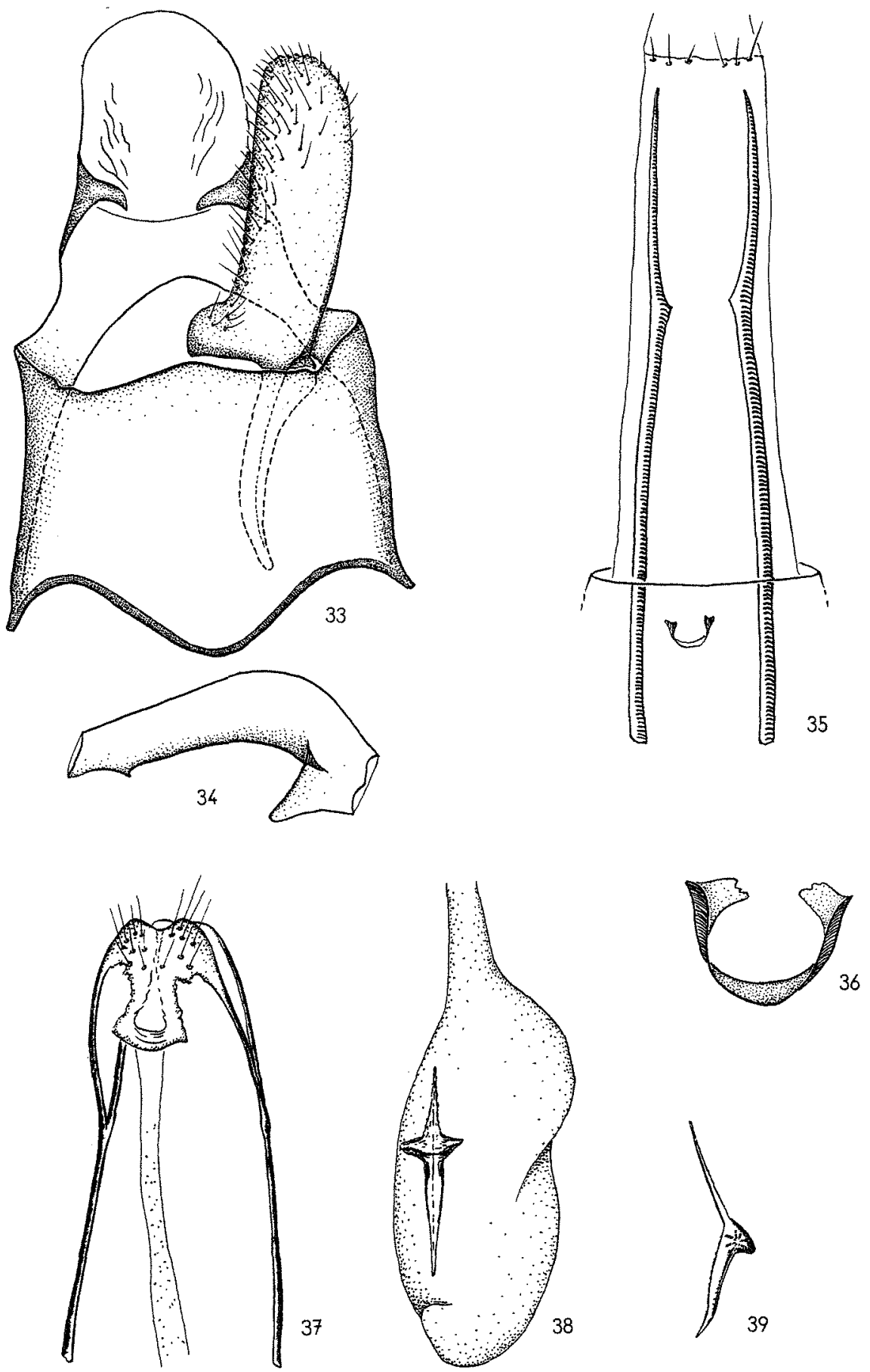

Figs 33-36: Tenaga nigripunctella (HAWORTH): 33-34 - o genitalia (one valva removed, aedeagus (fig. 34) separated), 35-36 - o genitalia (fig. 36: sclerotization in the ductus busae enlarged). Figs 37-39: Stenoptinea cyaneimarmorella (MnurèRE). o genitalia (37: ostium-complex, 38: corpus bursae with signum, 39: signum laterally). 

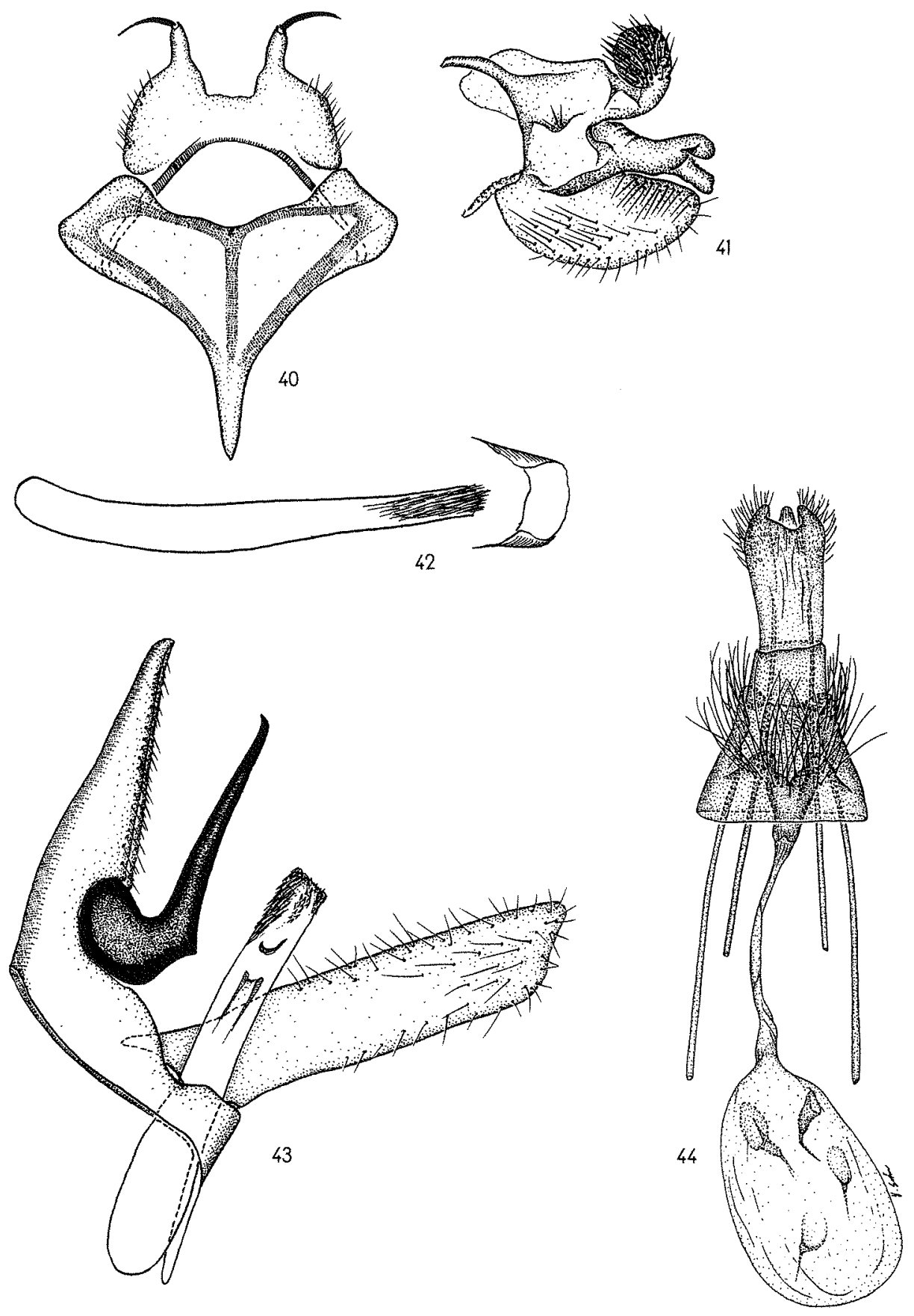

Figs 40-42: Stenoptinea ganeimarmorella (MULIIERE): o genitalia (40: uncus-tegumen-complex, 41: valva, 42: aedeagus + anellus). Figs 43-44: Ceratobia oxymora (MEYRICK): 43 - ơ genitalia (one valva removed), $44-q$ genitalia (drawing made by D. DAVIS). 


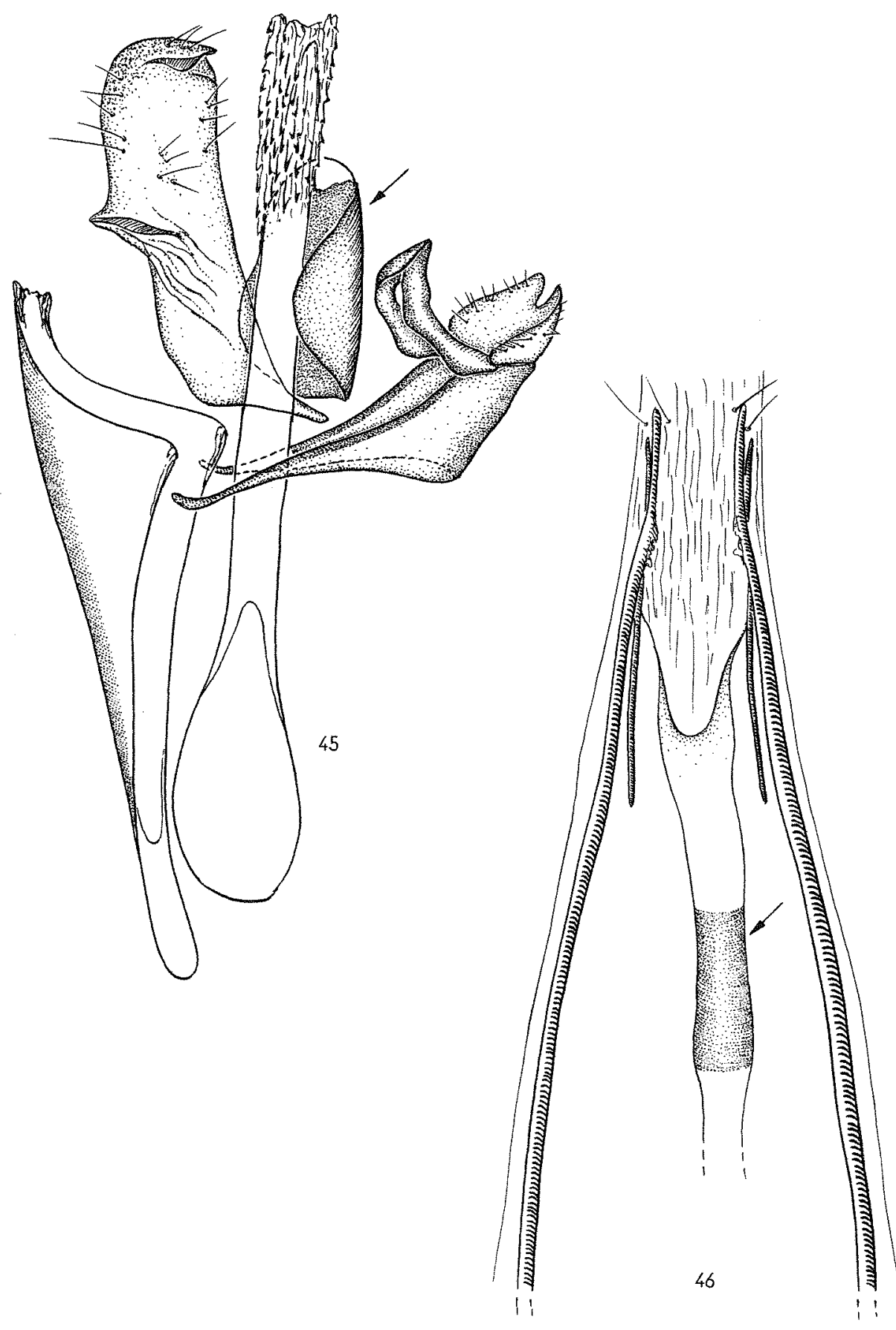

Figs 45-46: Trichophaga robinsoni nom. nov. : 45 - o genitalia (one valva removed), 46 - + genitalia. 


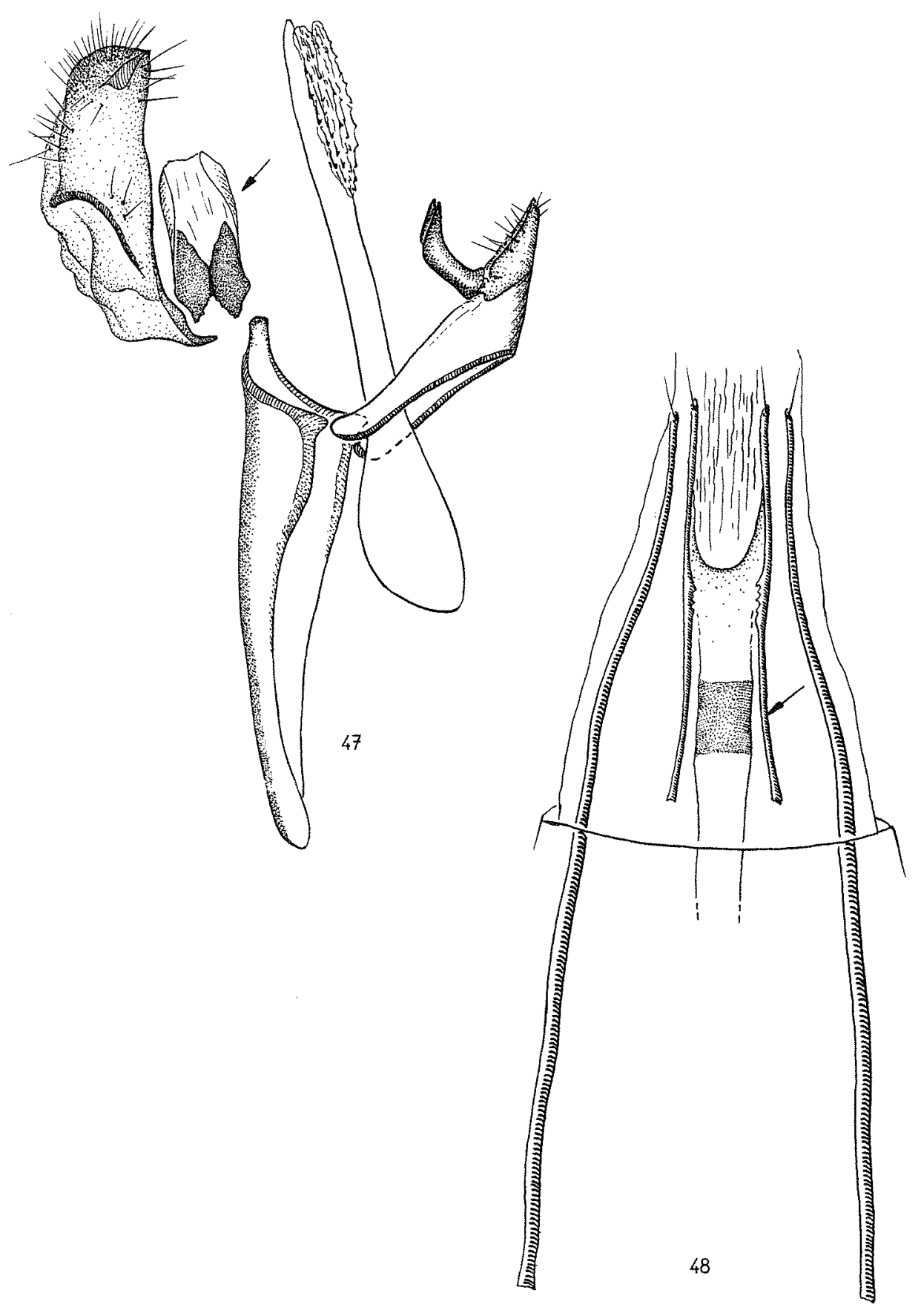

Figs 47-48: Trichophaga bipartitella (RAGONOT): $47-0$ genitalia (one valva removed), 48 - + genitalia. 

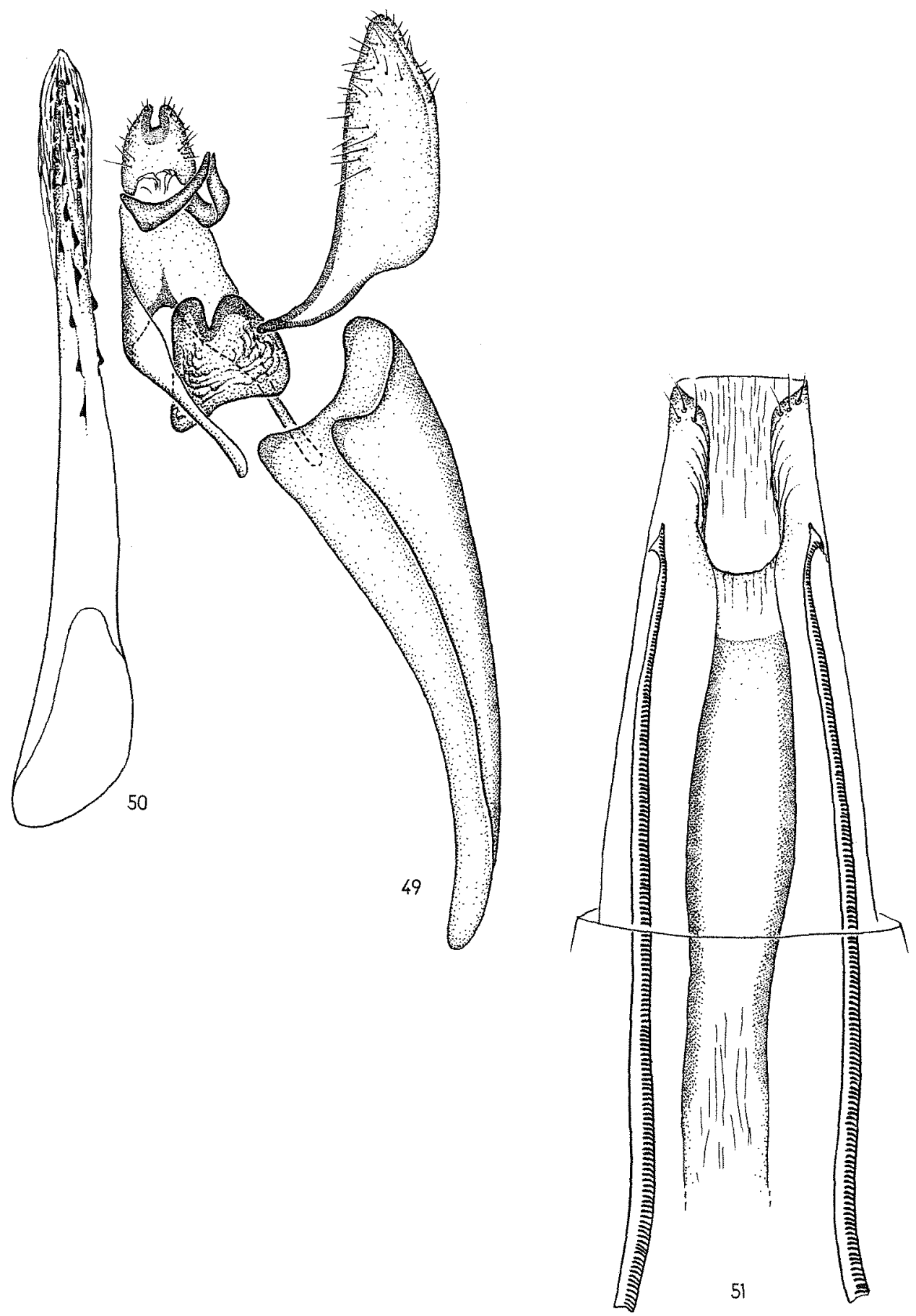

Figs 49-51: Trichophaga tapetzella (LINNAEUS): 49-50 - o genitalia (one valva removed, aedeagus (50) separated), 51- $q$ genitalia. 
Beitt. Ent. 51 (2001) 1

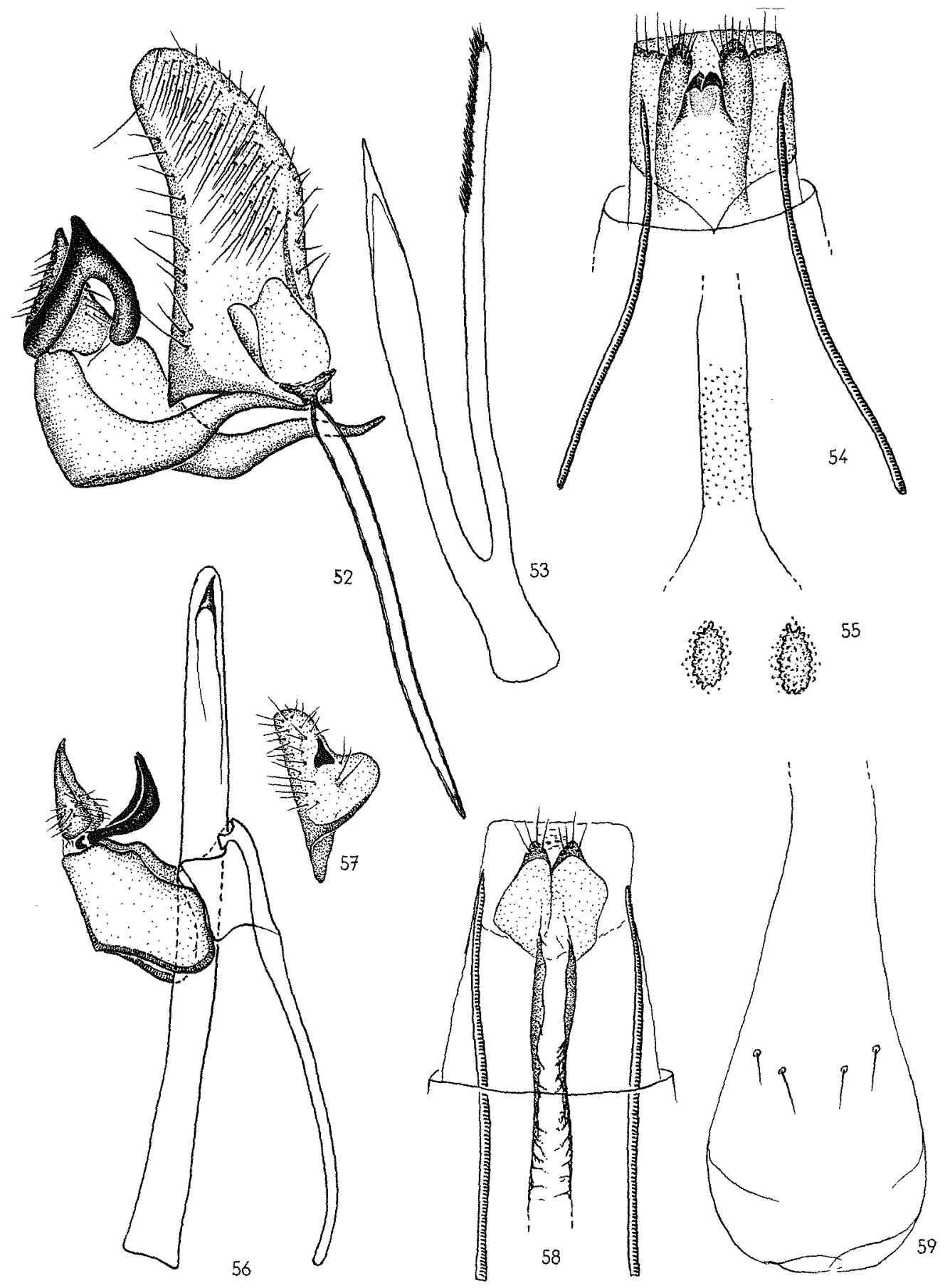

Figs 52-55: Praeacedes atomasella (WALKER): 52-53 - o genitalia (one valva removed, aedeagus (53) separated), 54-55 - \& genitalia (signa (55) enlarged); figs 56-59: Tineola bisselleella (Hunnex + ductus bursae, genitalia (one valva removed, valv - corpus bursae with signa).
59) 

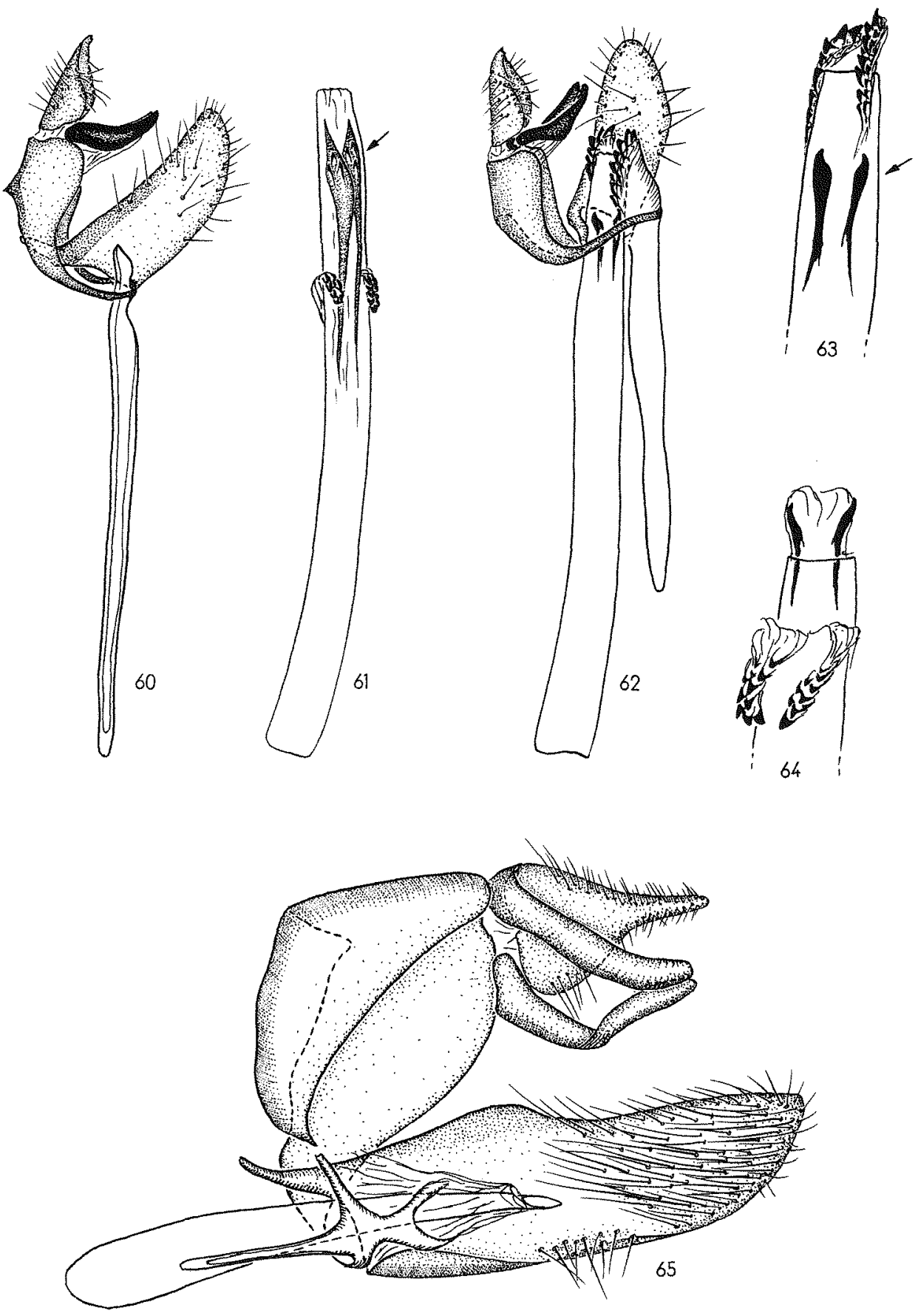

Figs 60-61: Tinea murariella (STAUDINGER) ơ genitalia (one valva removed, aedeagus separated); figs 62-64: Tinea dubiella (STAINTON) o genitalia (one valva removed, tip of the aedeagus + anellus, enlarged, various riews $(63,64)$ ); fig. 65: Tinea trinotella (THUNBERG) o genitalia (one valva removed). 

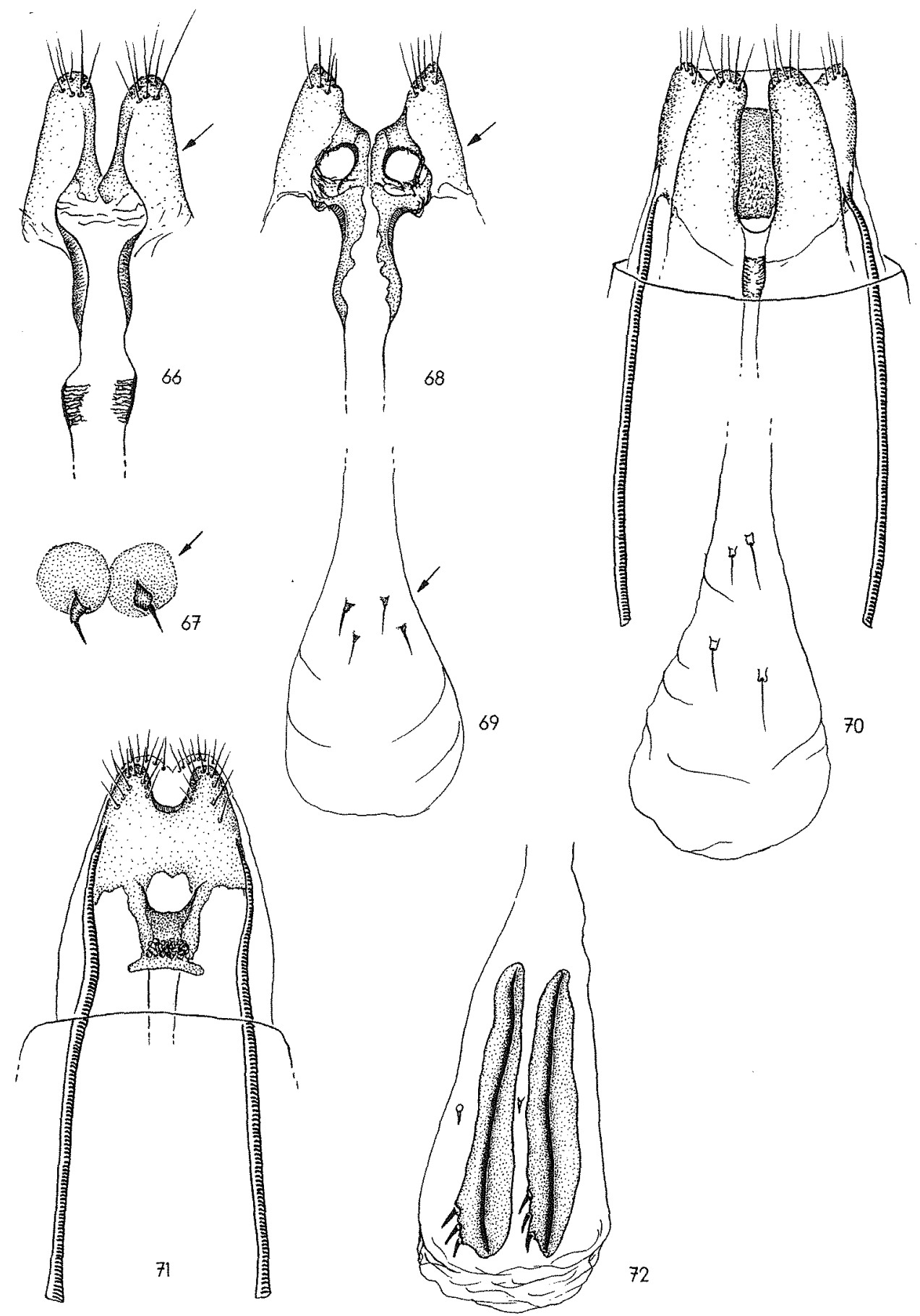

Figs 66-67: Tinea muraniella (STAUDINGER) \& genitalia : 66 - ostium + ductus bursae, 67 - signa, enlarged); figs 68-69: Tinea dubiella (STAINTON) o genitalia: 68 - ostium + ductus bursae, 69 - corpus bursae with signa; fig. 70: Tinea trinotella (THUNBERG) of genitalia; figs 71-72: Niditinea fuscella (LINNAEUS) o genitalia: 71ostium, 72 - corpus bursae with signa. 

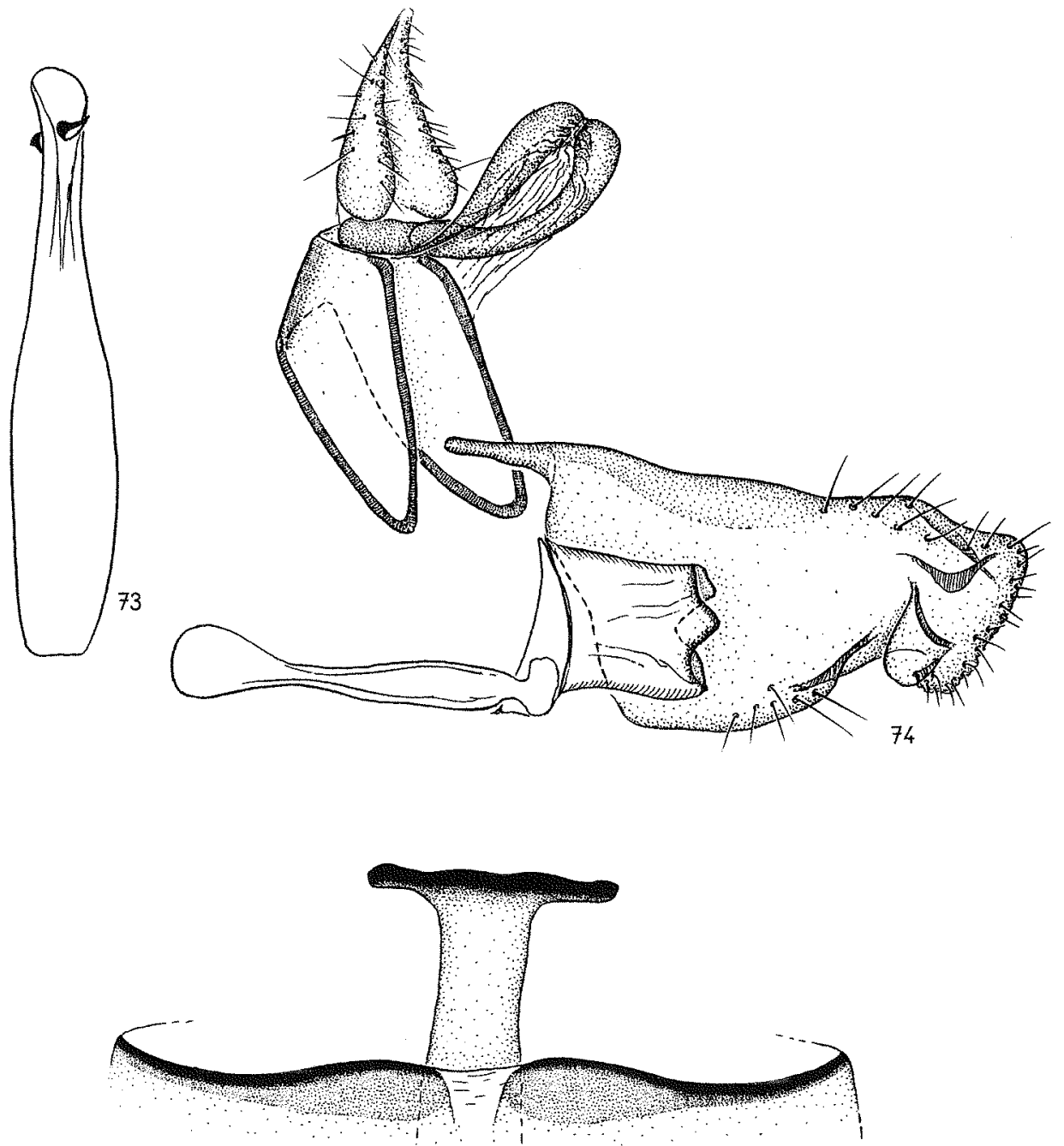

75

Figs 73-75: Niditinea fuscella (LINNAEUS): 73-74 - o genitalia (one valva removed, aedeagus separated), fig. 75 - sklerotization of the last abdominal sternit of the male. 

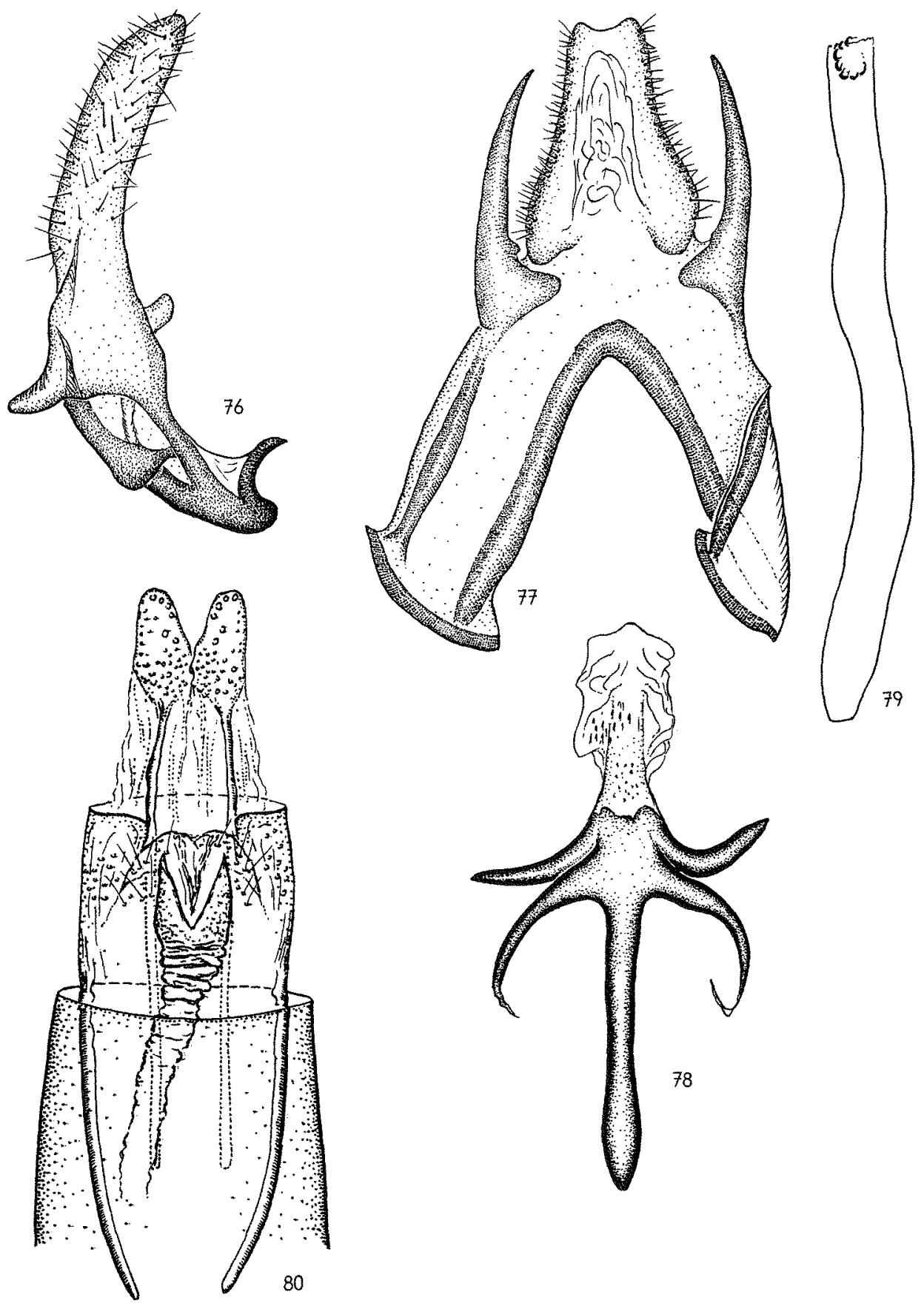

Figs 76-80: Phaereoeca allutella (REBEL): - $\sigma^{*}$ genitalia (one valva removed, aedeagus separated; valva (76), uncus-tegumen-complex (77), vinculum-saccus-complex (78), aedeagus (79)), 80 - + genitalia (drawing of G. Petersen). 

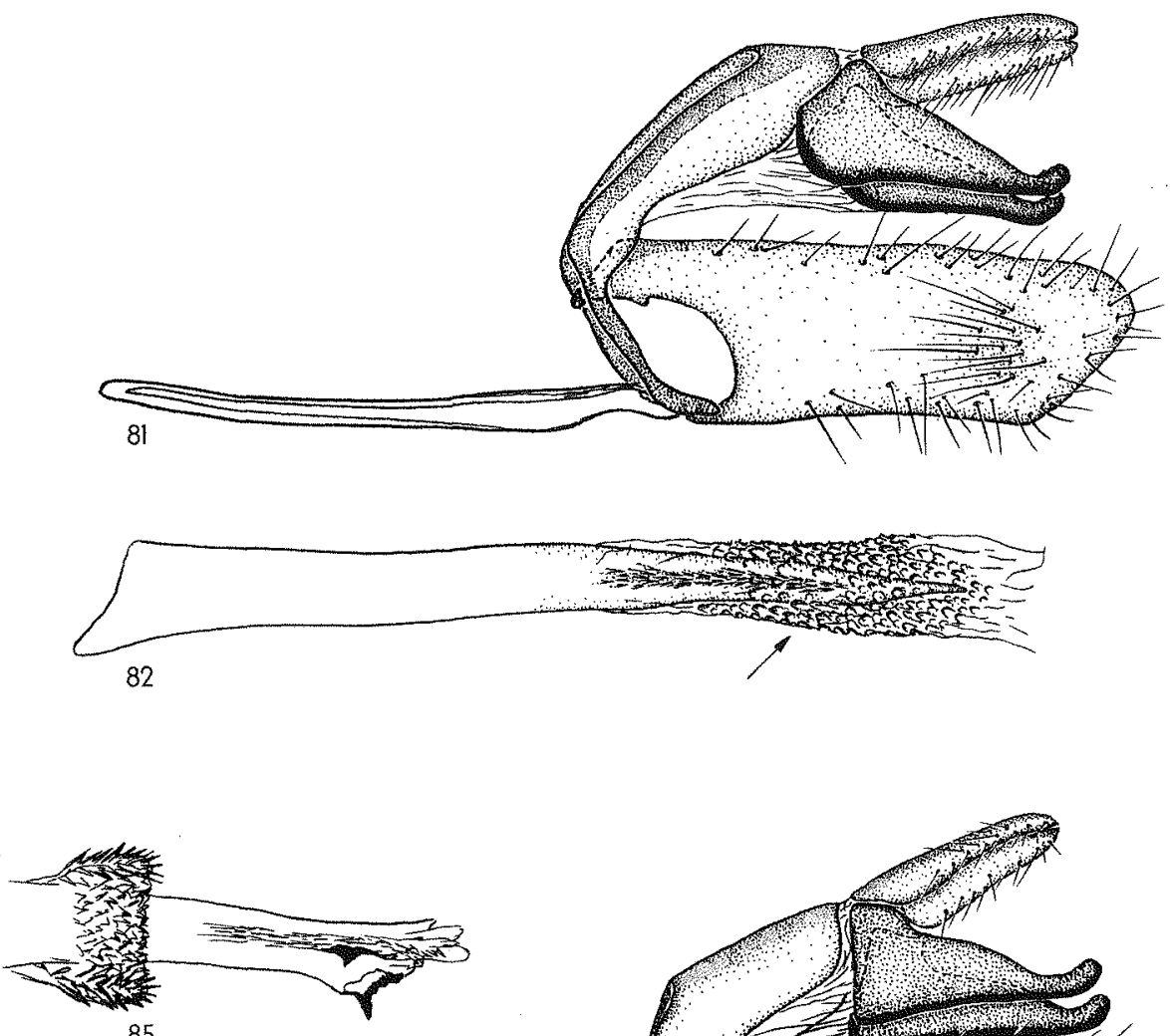

85
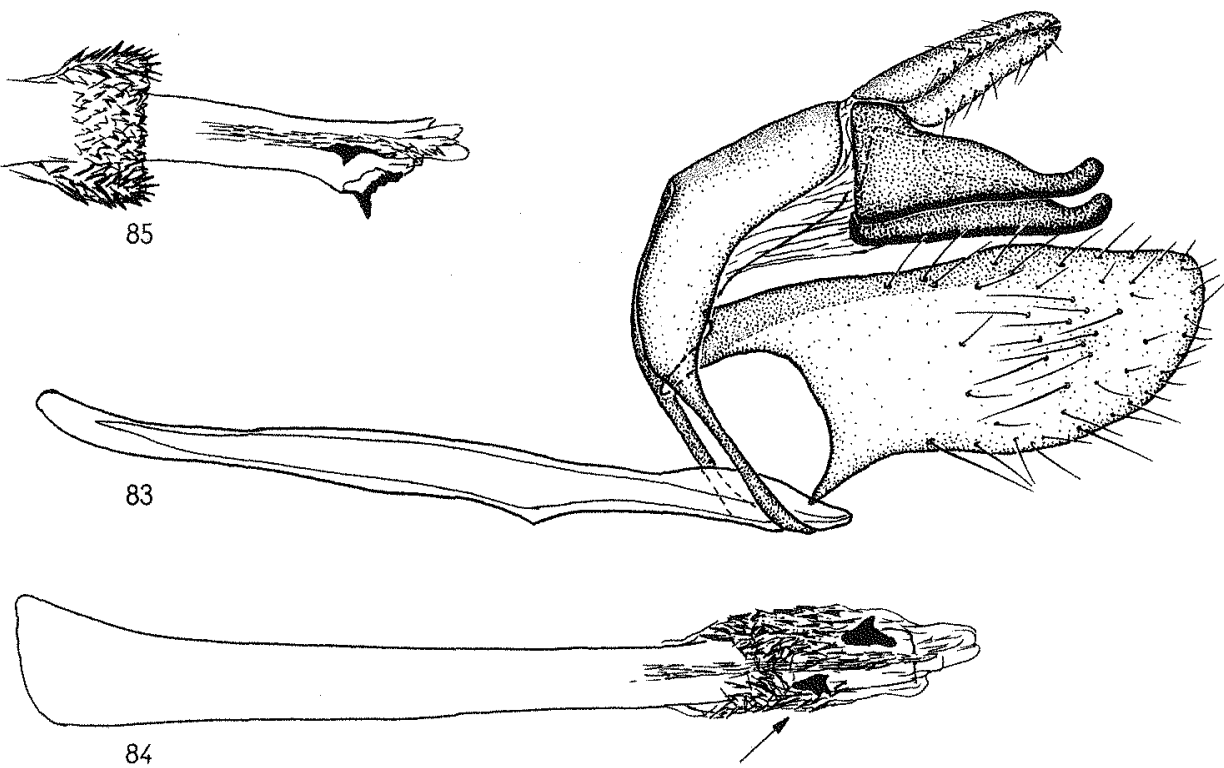

Figs 81-82: Monopis crocicapitella (CLEMENS) ơ genitalia (one valva removed, aedeagus separated); figs 8385: Monopis nigricantella (MILLIËRE) ơ genitalia (one valva removed, aedeagus separated, on fig. 85: tip of the aedeagus in other view. 

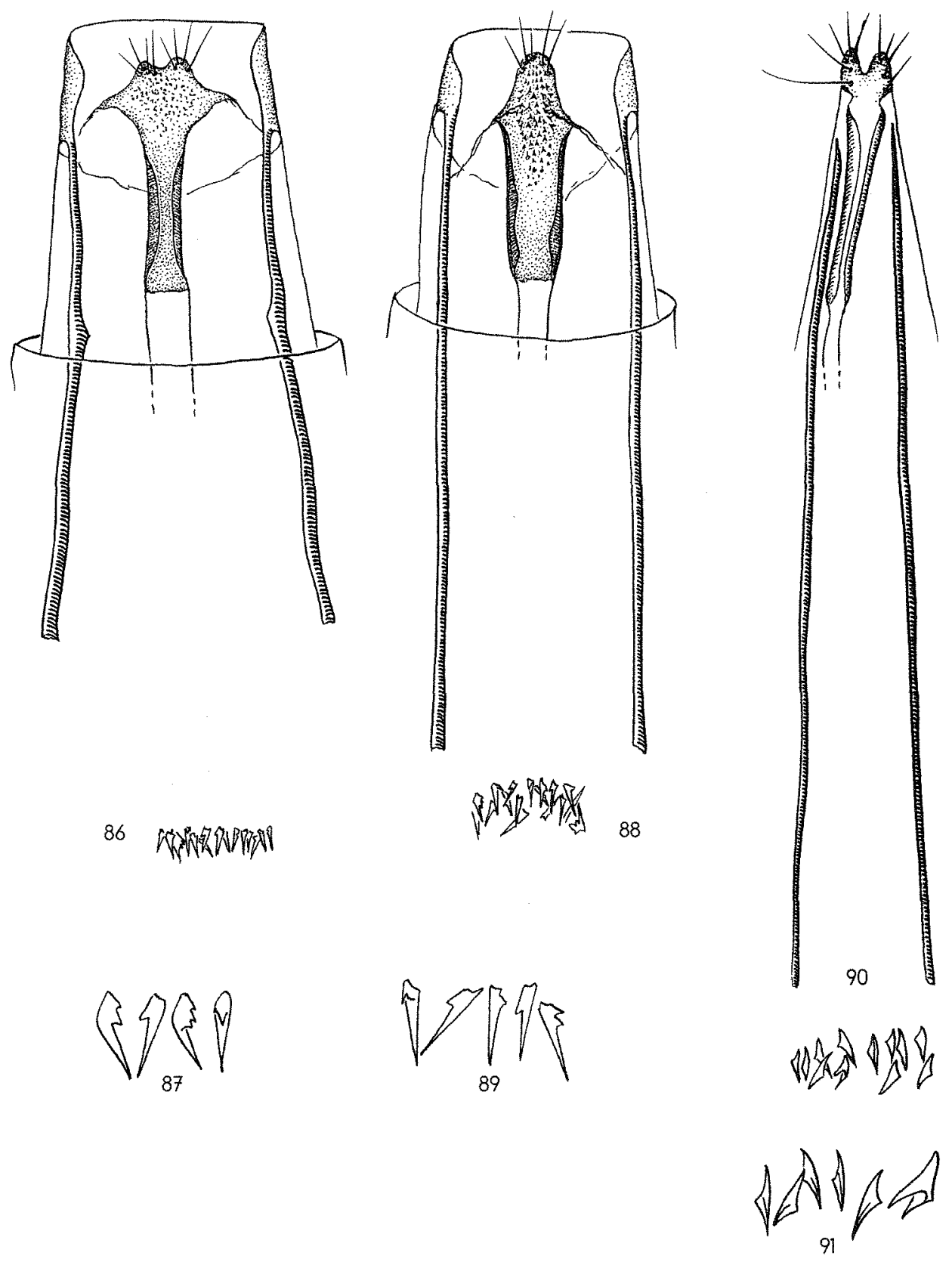

Figs 86-87: Monopis crocicapitella (CLEMENS) \& genitalia (87 - signa, enlarged); Figs 88-89: Monopis nigricantella (MILLIERE) + genitalia (89: signa, enlarged); figs 90-91: Monopis barbarosi (KOÇAK) $\&$ genitalia (91: signa, enlarged). 

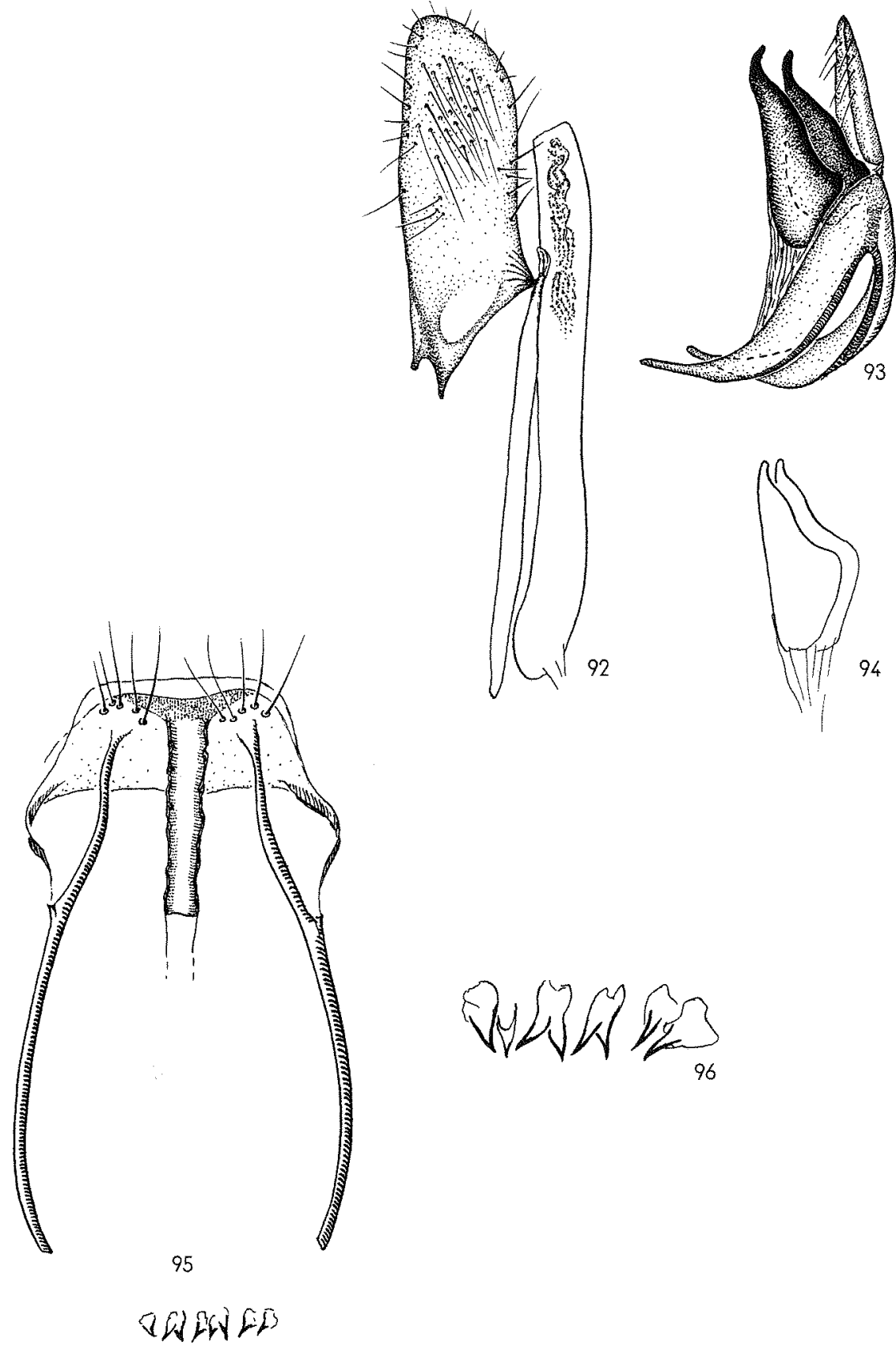

Figs 92-96: Monopis benderickxi sp. n.: 92-94 - o genitalia (one valva removed, valva + saccus + aedeagus (92), uncus-Tegumen-complex (93) separated, variation in the size of gnathos (94)), 95-96 - $q$ genitalia (96: signa enlarged). 

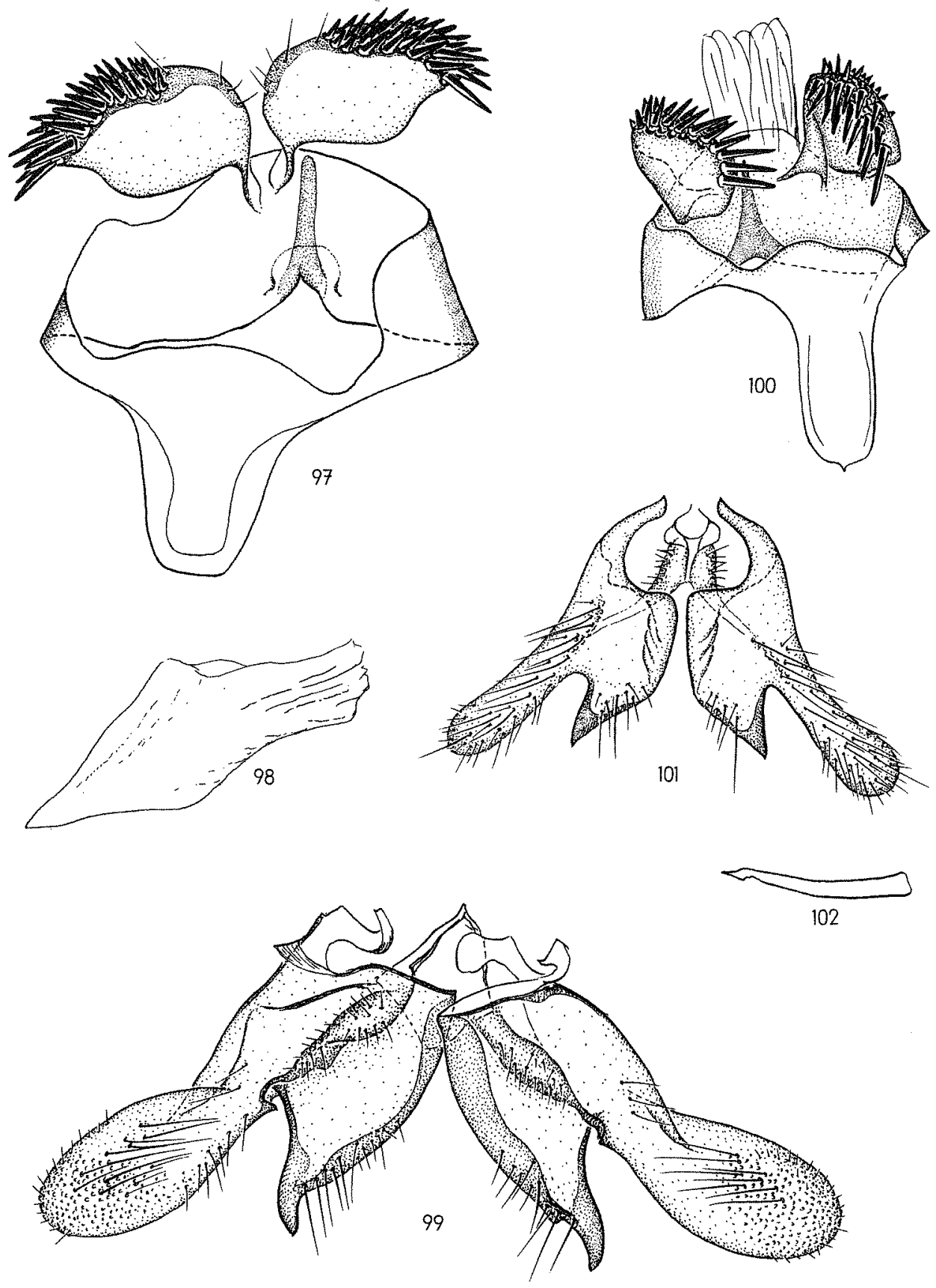

Figs 97-99: Opoogona sacchari (BOJER) ơ genitalia: 97 - uncus-tegumen-vinculum, 98 - aedeagus, 99 - valvae; figs 100-102: Opogona omoscopa (MEYRICK) ơ genitalia: 100 - uncus-tegumen-vinculum, 101-valvae, 102 - aedeagus. 

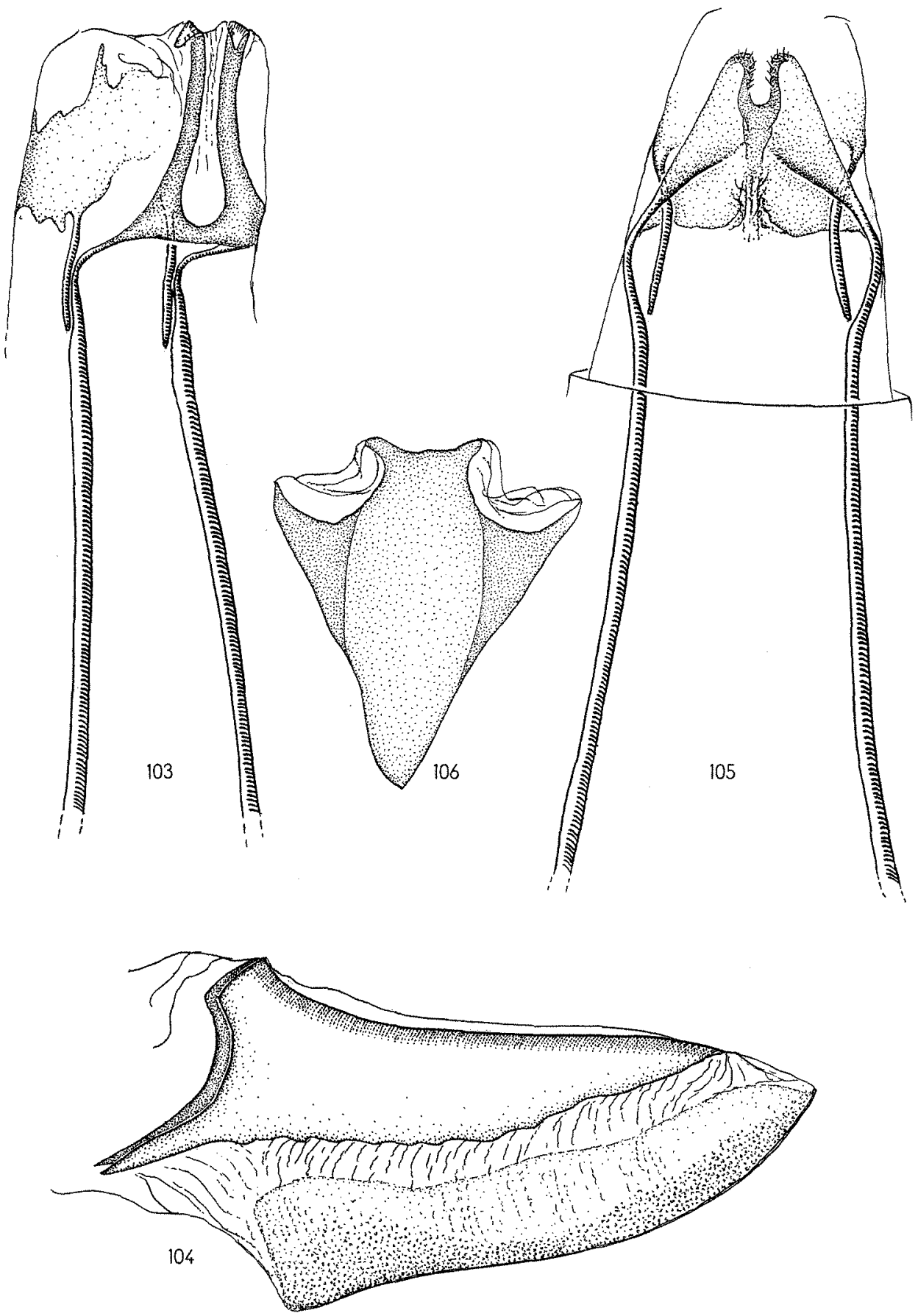

Figs 103-104: Opogona sacchari (BOJER) + genitalia: 103 - ostium, 104 - signum; figs 105-106: Opogona omoscopa (MEYRCK) 9 genitalia: 105 - ostium, 106 - signum. 


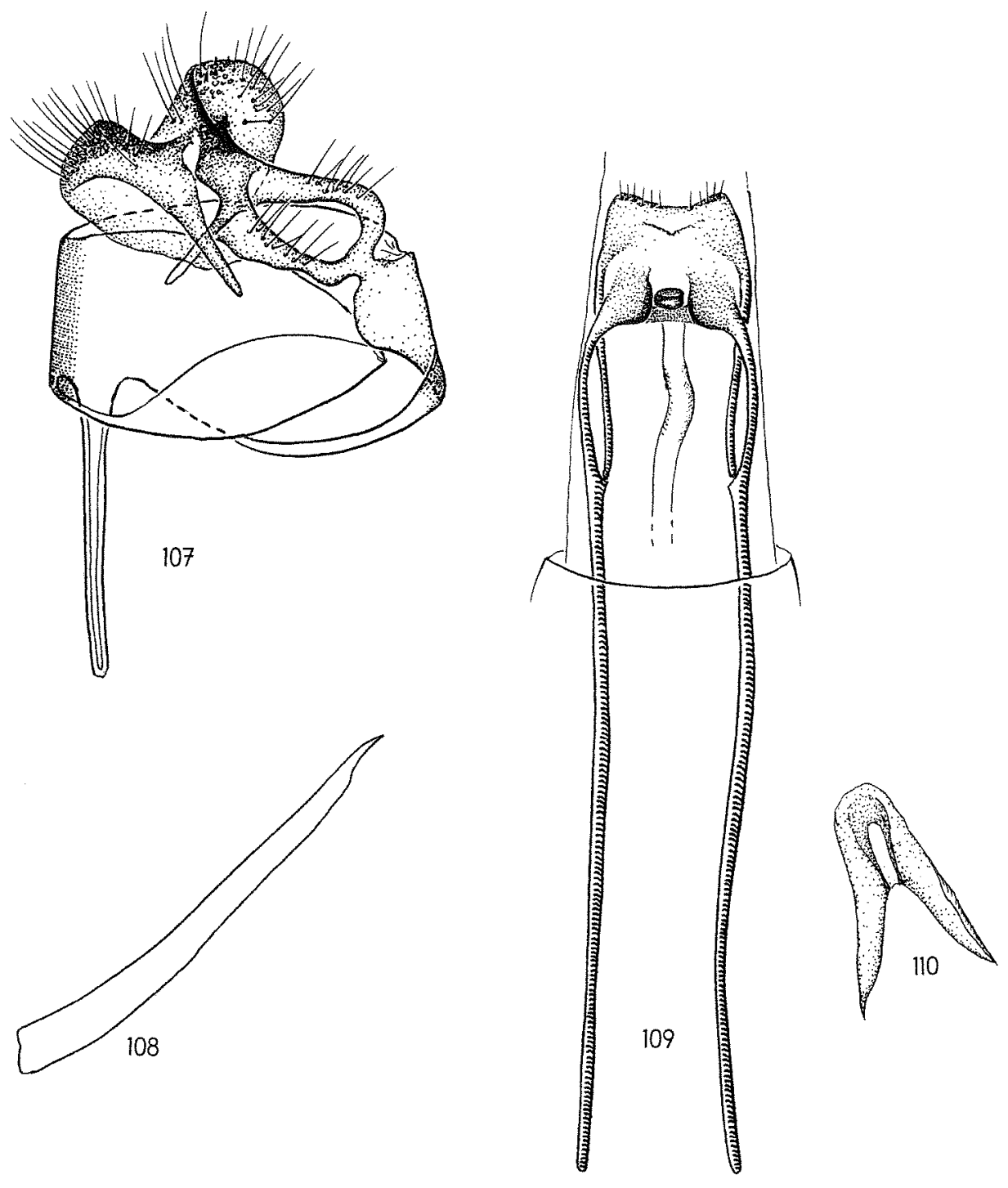

Figs 107-110: Oenopbila v-flava (HAWORTH): 107-108 - ơ genitalia (aedeagus sepatated), 109-110 - o genitalia (110: signa, enlarged). 

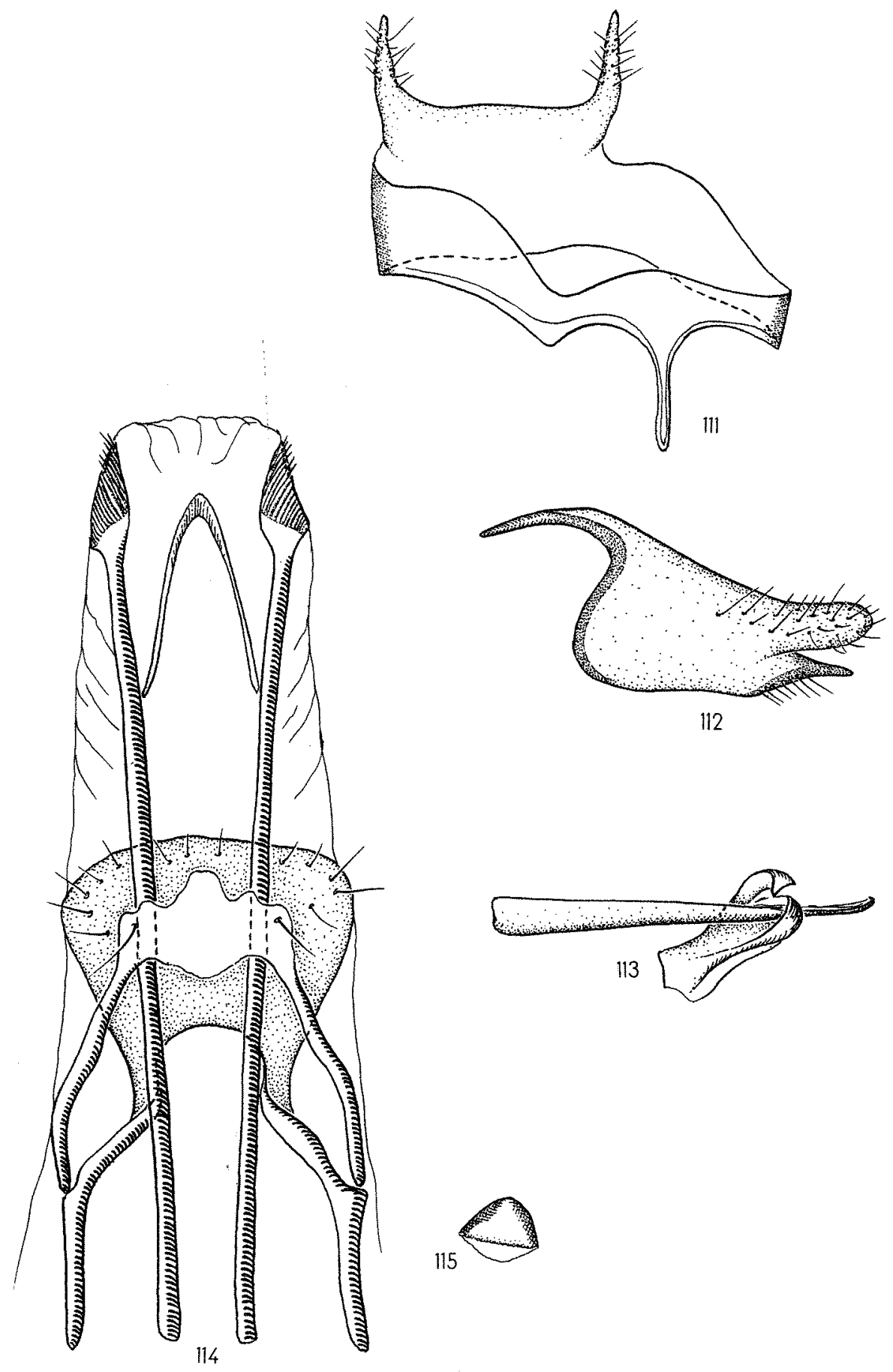

115

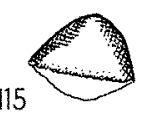

Figs 111-115: Psychoides filicivora (MEYRICK): 111-113 - o genitalia (uncus-tegumen-vinculum (111), valva (112), aedeagus + anellus (113)), 114-115 - o genitalia (115: signum, enlarged). 


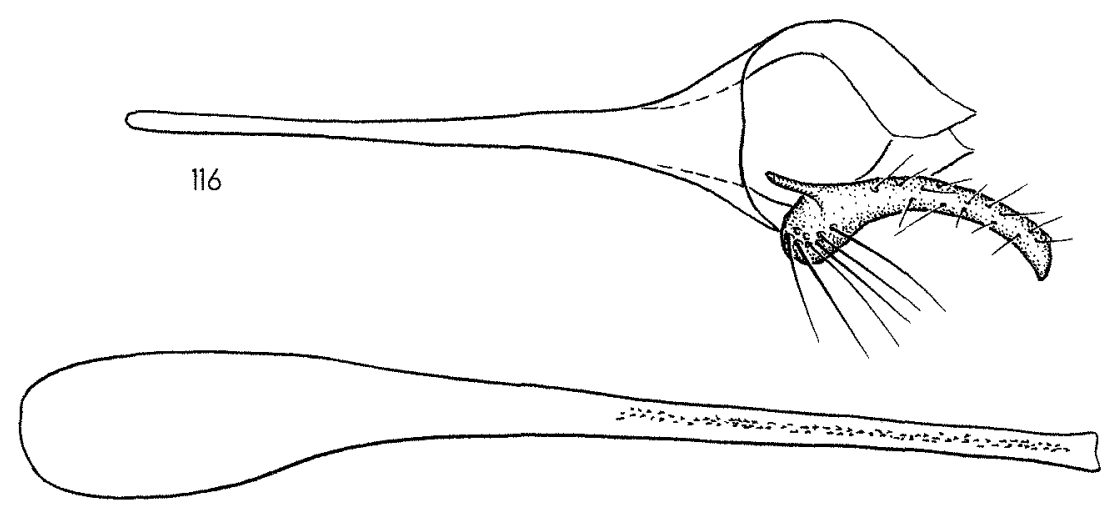

117
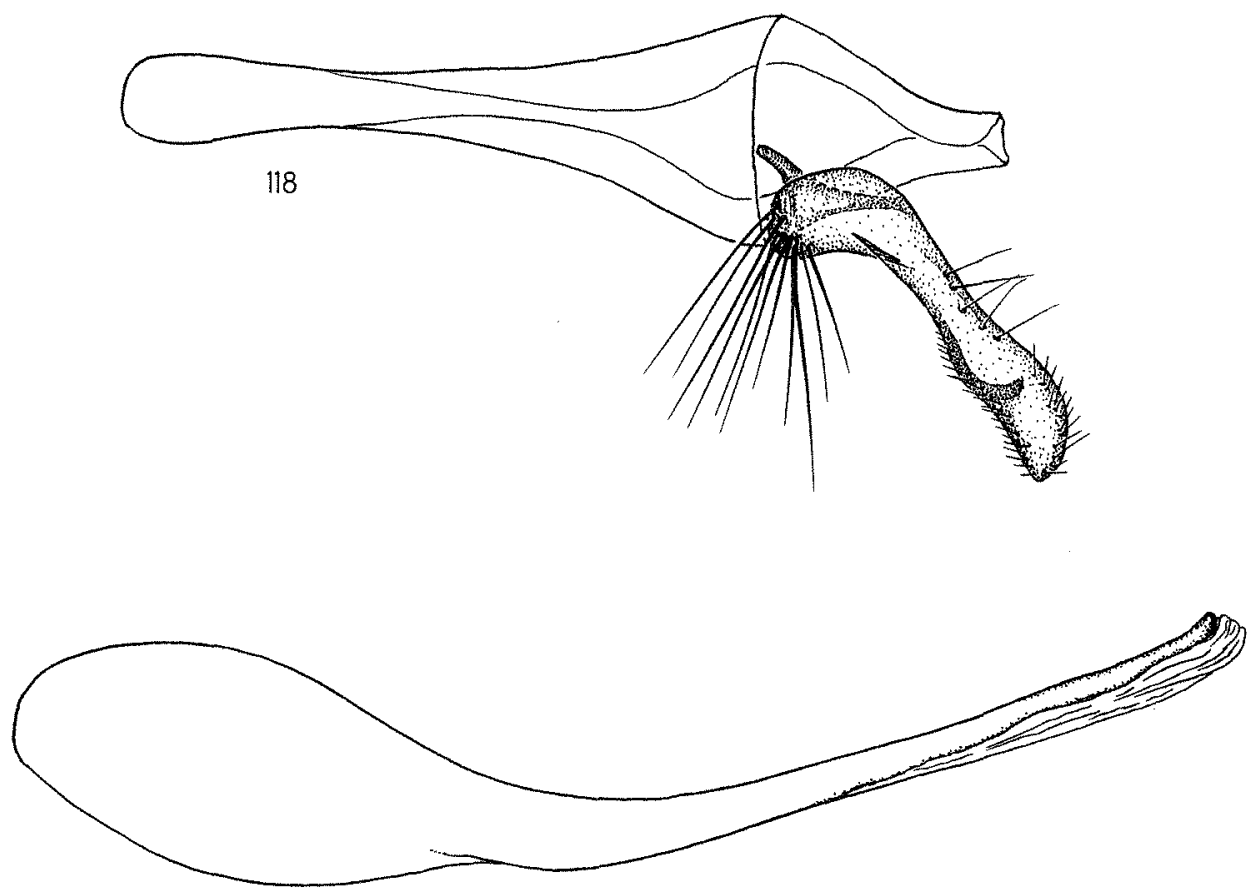

119

Figs 116-117: Acrolepiopsis vesperella (ZELLER) o genitalia (one valva removed, aedeagus separated); figs 118119: Acrolepidopsis mauli sp. n. o genitalia (one valva removed, aedeagus separated). 

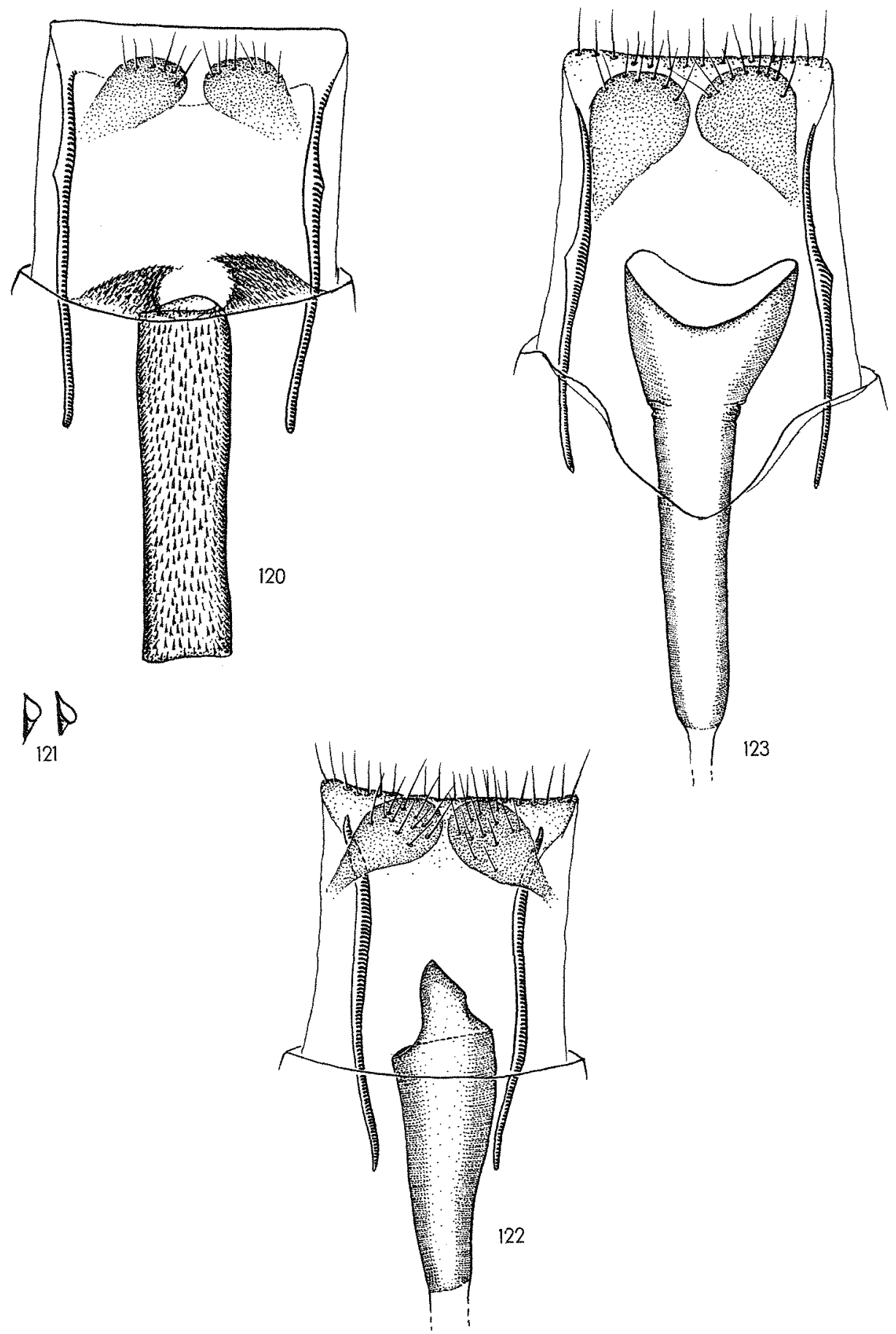

Figs 120-121: Acrolepiopsis vesperella (ZELLER). I genitalia (ostium + corpus bursae, signa (121) separated); fig. 122: Acrolepidopsis mauli sp. n. o genitalia; fig. 123: Acrolepiopsis infundibulosa sp. n. o genitalia. 

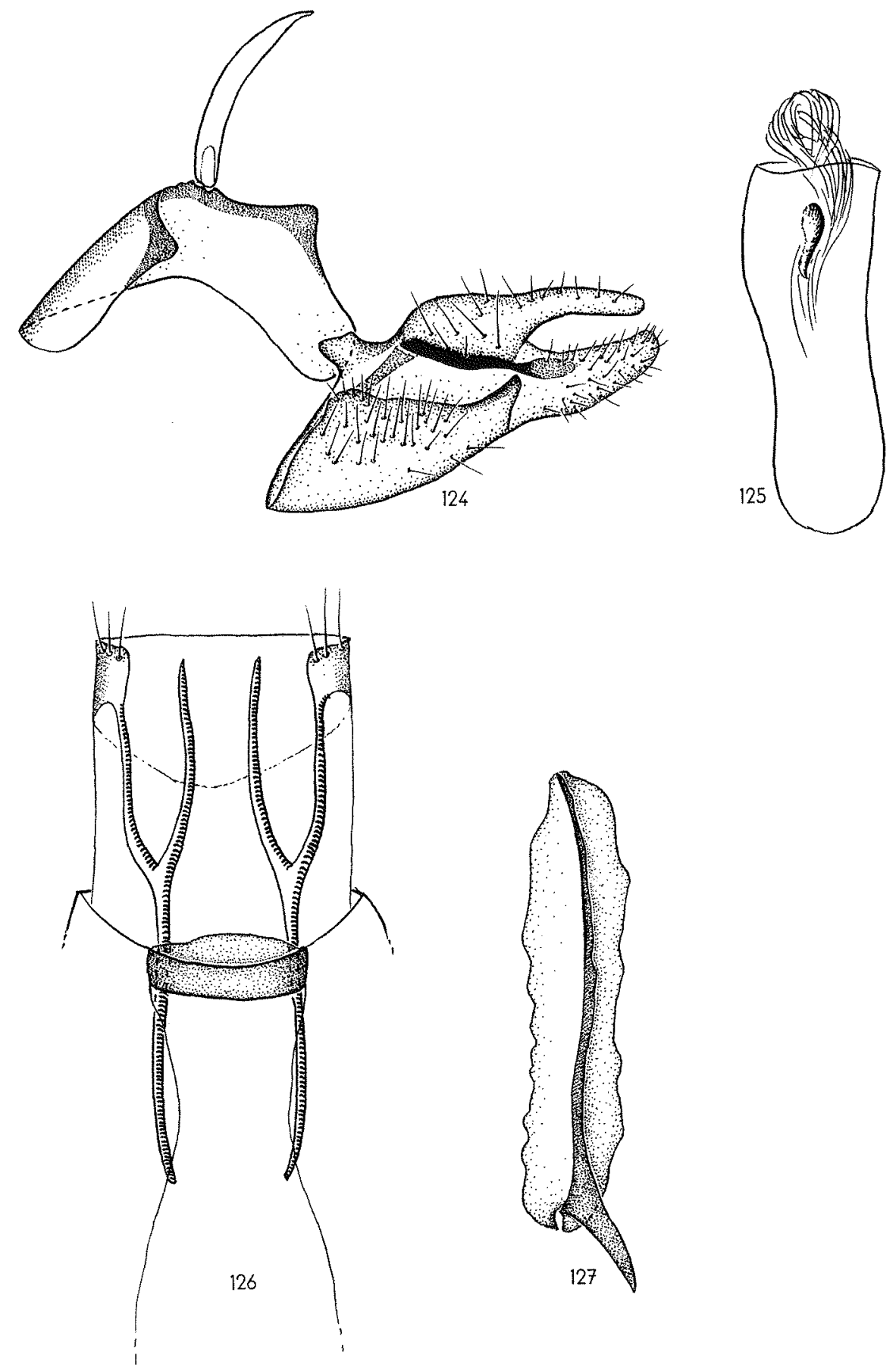

Figs 124-127: Epermenia aequidentella (HOFMANN): 124-125 - ơ genitalia (one valva removed, aedeagus separated), 126-127 - \& genitalia (signum (127) separated). 